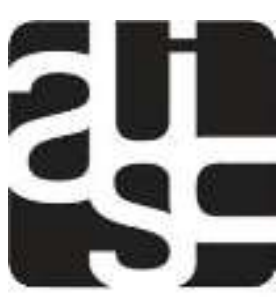

iau usp
Universidade de São Paulo

Instituto de Arquitetura e

Urbanismo

Programa de Pós Graduação

\title{
Gestão de obras públicas: \\ Um diagnóstico sobre aditivos de contratos
}

Dissertação de Mestrado 
AUTORIZO A REPRODUÇĀO TOTAL OU PARCIAL DESTE TRABALHO, POR QUALQUER MEIO CONVENCIONAL OU ELETRÓNICO, PARA FINS DE ESTUDO E PESQUISA, DESDE QUE CITADA A FONTE.

$\mathrm{R} 225 \mathrm{~g}$

Rasmussen, Ana Flora Machado

Gestão de obras públicas: um diagnóstico sobre aditivos de contato / Ana Flora Machado Rasmussen; orientador Prof. Marcio Minto Fabricio. São Carlos, 2013.

Dissertação (Mestrado) - Programa de Pós-Graduação em Arquitetura e Urbanismo e Area de Concentraçăo em Arquitetura, Urbanismo e Tecnologia -- Instituto de Arquitetura e Urbanismo da Universidade de Săo Paulo, 2013.

1. Gestão. 2. Obras públicas. 3. Aditivos. 4. Cronograma. 5. Orçamento. I. Título. 


\section{Gestão de obras públicas: um diagnóstico sobre aditivos de contratos}

Dissertação apresentada ao Instituto de Arquitetura e Urbanismo da Universidade de São Paulo para obtenção do título de mestre em arquitetura e urbanismo

Área de concentração: Arquitetura, Urbanismo e Tecnologia.

Orientador: Professor Doutor Marcio Minto Fabrício

São Carlos

2013 


\section{FOLHA DE JULGAMENTO}

Candidato: Arquiteta e Urbanista Ana Flora Machado Rasmussen.

Título da dissertação: "Gestão de obras públicas: um diagnóstico sobre aditivo de contrato".

Data da defesa: 07/06/2013.

Comissão Julgadora:

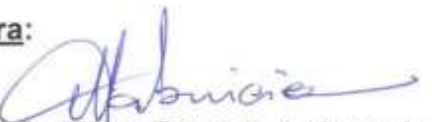

Prof. Associado Márcio Minto Fabricio (orientador)

(Instituto de Arquitetura e Urbanismo - IAU/USP)

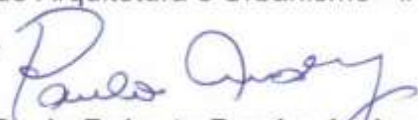

Prof. Dr. Paulo Roberto Pereira Andery

(Universidade Federal de Minas Gerais - UFMG)

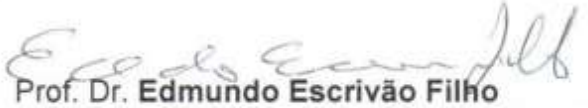

(Escola de Engenharia de São Carlos - USP)
Resultado:

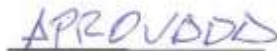

APROUROA

APROVADA

Presidente e Coordenador do Programa de Pós-Graduação em Arquitetura Urbanismo: Professor Titular Renato Luiz Sobral Anelli 
Dedicatória

Ao meu pai, José Einar, (in memoriam) que me ensinou grandes princípios de vida. Ao Pedro, pela ajuda, força, companheirismo e amor.

À minha mãe, Maria de Lourdes, que soube, como ninguém, ser mãe, com tudo o que isso possa significar. Dedico, principalmente, ao Brasil. País tão bonito que precisa de mais respeito. 

Agradeço à Universidade de São Paulo pela oportunidade de realizar esta pesquisa.

Agradeço ao Instituto de Arquitetura e Urbanismo, em especial aos funcionários, sempre tão solícitos e prontos em ajudar.

Agradeço a minha mãe pelo constante apoio em todo o período.

Agradeço ao Pedro pelo amor e constante apoio que não me deixaram desistir de lutar.

À Capes, pelo apoio financeiro.

Agradeço à banca pela disponibilidade, orientações e por compartilhar seus conhecimentos.

Ao meu orientador, prof. Marcio Minto Fabrício.

Agradeço ao prof. Edmundo Escrivão Filho por entender as dificuldades enfrentadas por mim ocorridas durante essa pesquisa, e por saber estender a mão de forma tão carinhosa e atenciosa.

Aos funcionários da prefeitura estudada, pois foram sempre muito solícitos em ajudar de todas as formas possíveis.

Aos amigos que me ajudaram, de diversas formas, nestes anos pesquisa. 


O objetivo principal com esta pesquisa é analisar as ocorrências de aditivos de tempo e de serviço em contratos de obras públicas para construção e ampliação de equipamentos de saúde e educação. O tema da pesquisa é o contrato de obra pública que pode ser entendido como o documento no qual ficam estabelecidos o prazo e o orçamento para a construção ou ampliação dos equipamentos públicos estudados. O aditivo de contrato é o instrumento jurídico utilizado para que se possa alterar limites de tempo e de serviço, sem que haja a necessidade de rescisão de contrato e da elaboração de um novo processo licitatório. O método de pesquisa fundamentou-se na abordagem qualitativa com uso de dados quantitativos e qualitativos. A coleta dos dados quantitativos baseou-se em análise de documentos e dos dados qualitativos em questionário com questões abertas respondidas pelos engenheiros da prefeitura estudada, os quais foram responsáveis pela fiscalização das obras. O principal resultado encontrado foi a excessiva quantidade de aditivos de tempo enquanto que os de serviço estão controlados, mas devido às leis brasileiras, e não em razão de um planejamento eficiente. A pesquisa deixa como contribuição um roteiro para análise de aditivo em obras públicas que pode ser replicada tanto em outras prefeituras municipais como em outras esferas do governo.

Palavras chave: obras públicas, aditivos, gestão, cronograma, orçamento. 

The main objective of this research is to analyze the occurrences of additives and time of service in public works contracts for the construction and expansion of health facilities and education. The research topic is the contract for public work which can be understood as the document in which are set the deadline and the budget for the construction or expansion of public facilities studied. The additive of contract is the legal instrument that can be used to change time limits and service, without the need for termination of contract and the drafting of a new bidding process. The research method was based on a qualitative approach with the use of quantitative and qualitative data. Data collection was based on quantitative analysis of documents and data in qualitative questionnaire with open questions answered by engineers studied the city, which were responsible for supervising the works. The main result was found excessive amounts of additives of time while the service are controlled, but due to Brazilian law, and not due to efficient planning. The research makes contribution as a roadmap for analyzing additive in public works which can be replicated in other municipalities as much as in other spheres of government.

Key-words: management, public works, additives, schedule, budget 



$\begin{array}{ll}\text { AHP } & \text { Analytic Hierarchy Process, } \\ \text { APO } & \text { Avaliação pós ocupação } \\ \text { CEMEI } & \text { Centro Municipal de Educação Infantil } \\ \text { COI } & \text { Comitê Olímpico Internacional } \\ \text { DNJ } & \text { Departamento de Negócios Jurídicos } \\ \text { EMEB } & \text { Escola Municipal de Ensino Básico } \\ \text { FIFA } & \text { Fédération Internationale de Football Association } \\ \text { FMS } & \text { Fundo Municipal de Saúde } \\ \text { GIAP } & \text { Gerenciador Integrado de Administração Pública } \\ \text { SMPG } & \text { Secretaria Municipal de Planejamento e Gestão } \\ \text { SMO } & \text { Lei de Diretrizes Orçamentárias } \\ \text { SMMU } & \text { Secretaria Municipal de Educação } \\ \text { LF } & \text { Lei Federal } \\ \text { PMP } & \text { Parceria Público Privada } \\ & \end{array}$


Secretaria Municipal de Saúde

TCE

Tribunal de Contas do Estado

UBS

Unidade Básica de Saúde

UPA Unidade de Pronto Atendimento

USF Unidade de Saúde da Família 
Tabela 2-1. causas de atrasos de obras segundo Doloi et al (2012) - continua ....... 43

Tabela 2-2. Causas de atrasos de obras segundo Doloi et al (2012) - continua ....... 44

Tabela 2-3. Causas de atrasos de obras segundo Doloi et al (2012) - conclusão ..... 45

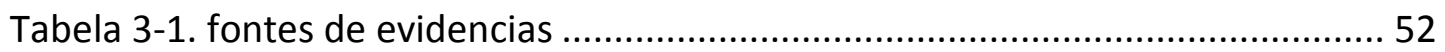

Tabela 3-2. Lista de obras levantadas de equipamentos de saúde........................... 55

Tabela 3-3. Lista de obras levantadas de equipamentos de educação ...................... 55

Tabela 3-4. tabela totalizadora de obras (continua) .......Erro! Indicador não definido.

Tabela 3-5. Tabela totalizadora de obras (continua).......Erro! Indicador não definido.

Tabela 3-6. . (continuação) tabela totalizadora dos dados (conclusão)Erro! Indicador não definido.

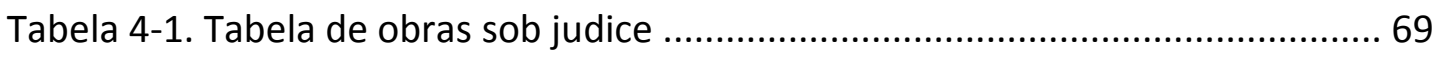

Tabela 4-2. Porcentagens de aditivos de tempo ..................................................... 71

Tabela 4-3. Tabela comparativa de aditivo de serviço ............................................. 75

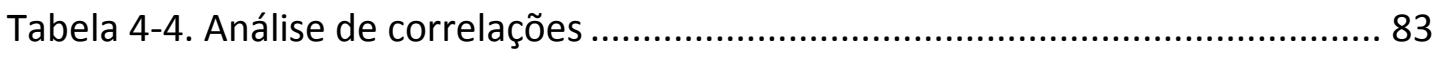

Tabela 0-1. possibilidades para primeiro campo do codificação das obras .............. 91

Tabela 0-2. Possibilidades para segundo campo da codificação das obras .............. 91

Tabela 0-3. Possibilidades para terceiro campo da codificação das obras ............... 91

Tabela 0-1. Tabela com localização dos processos para análise .............................. 92 

Gráfico 4-1. Porcentagem de Obras em processo judicial............................ 68

Gráfico 4-2. Porcentagem de obras com aditivos........................................ 71

Gráfico 4-3. Relação tempo estimado x tempo real ................................... 74

Gráfico 4-4. Relação custo estimado x valor contratado x custo real ........... 76

Gráfico 4-5. Relação entre valor contratado e custo real............................ 78

Gráfico 4-6. Relação entre o valor estimado e o valor contratado ................ 80

Gráfico 4-7. Relação entre Valor contratado e valor do aditivo..................... 82 



\section{Lista de Figuras}

Figura 3-1. Foto ilustrativa dos processos analisados. Fonte: autora 54 

1. INTRODUÇÃO........................................................................................26

1.1. ConTEXTUALIZAÇÃO DA PESQUISA............................................................................26

1.2. DeLIMITAÇÃ̃o do TEMA DA PESQUISA: ...........................................................28

1.3. FORMULAÇÃ̃ do PROBLEMA DA PESQUISA: .........................................................31

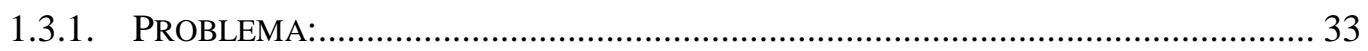

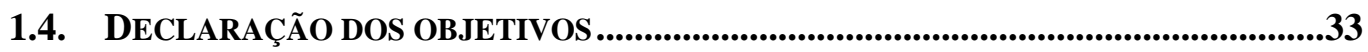

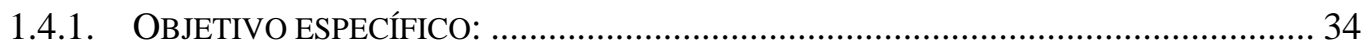

1.5. JUSTIFICATIVA ................................................................................................................34

1.6. ESTRUTURA DO TEXTO ..............................................................................................35

2. ADITIVOS EM CONTRATOS DE OBRAS PÚBLICAS .......................................37

2.1. CONCEITO DE ATRASO EM OBRAS....................................................................37

2.2. CAUSAS DE ATRASOS EM OBRAS PRIVADAS .....................................................38

2.3. CAUSAS DE ATRASOS EM OBRAS PÚBLICAS ......................................................39

2.4. QUESTÕES RELATIVAS AOS ORÇAMENTOS........................................................

2.5. MÉTODOS DE GESTÃO UTILIZADOS .............................................................................48

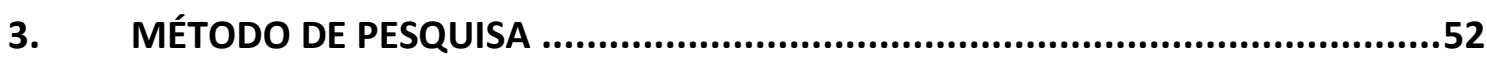

3.1. DESCRIÇÃO do ESTUDO DE CASO ...........................................................................53

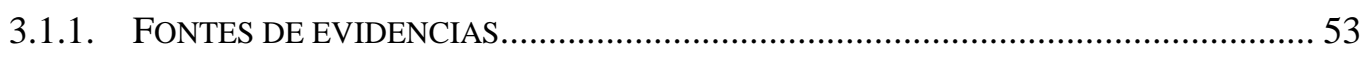

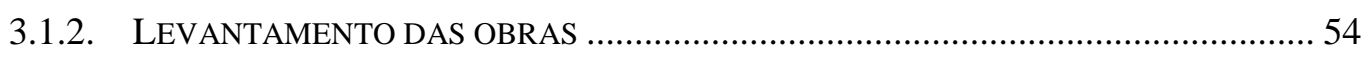

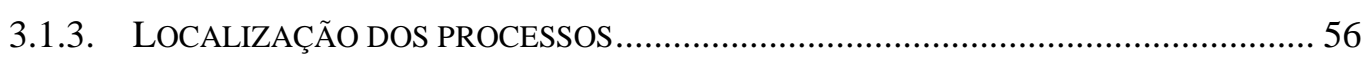

3.2. PROPOSTA DE ROTEIRO DE COLETA E ANÁLISE ....................................................60

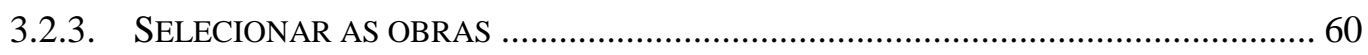

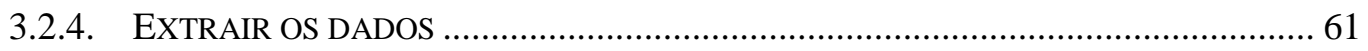

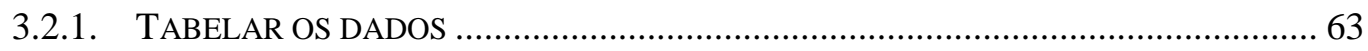

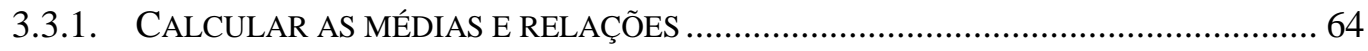




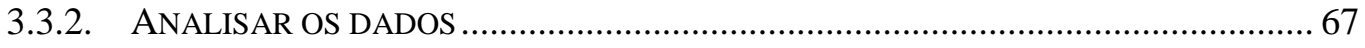

3.3.3. COEFICIENTE DE CORRELAÇÃO DE SPEARMAN $(\boldsymbol{\rho})$............................................ 67

4. ANÁLISE E INTERPRETAÇÃO DOS DADOS................................................ 68

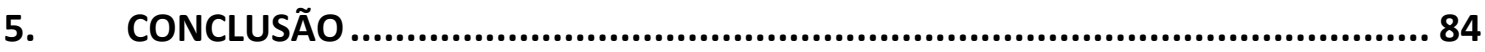

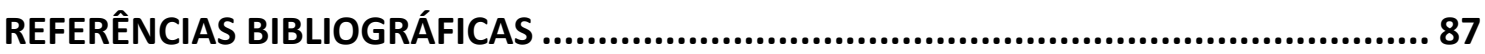

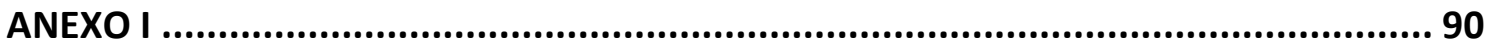

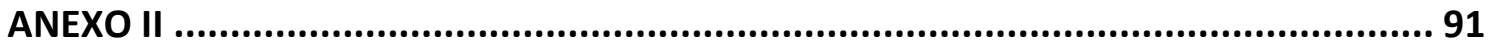

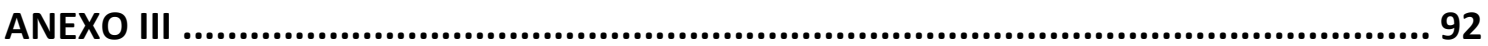

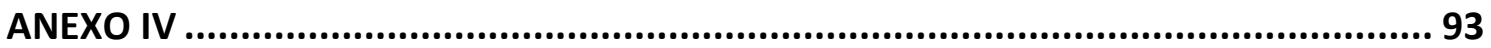

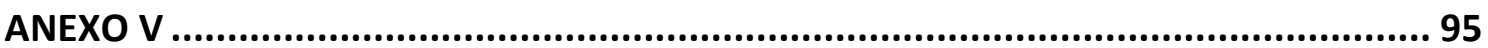

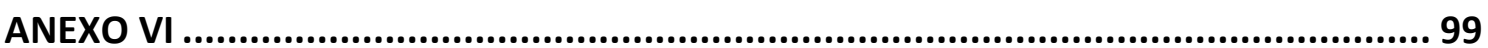

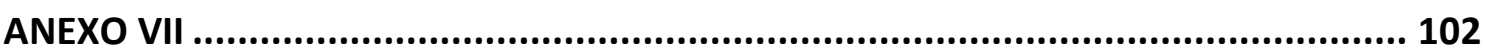

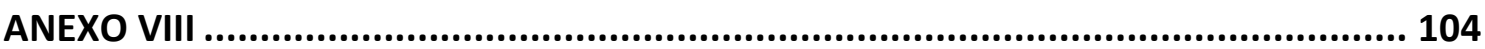

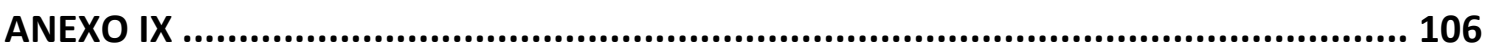






\section{INTRODUÇÃO}

\subsection{Contextualização da PESQuisa}

O número de possibilidades para pesquisas acadêmicas dentro do ramo da construção civil é muito amplo, sendo que a maior parte é focada em obras privadas. Estudos sobre obras públicas, no Brasil, começam a dar seus primeiros passos, porém ainda estão muito atrasados em relação ao pesquisado em outros países. Quando se trata de pesquisas internacionais sobre o assunto, a quantidade de pesquisas e o campo de abrangência dos assuntos estudados são maiores se comparados com as desenvolvidas no Brasil.

Dentre essa variedade encontrada, podem ser destacadas pesquisas sobre licitação, como Seydel e Olson (2001) que ressaltam as vantagens de se utilizar um processo de escolha baseada em múltiplos critérios, ao invés de somente o preço ser o fator decisivo, autores como Khalil e Gahfly (1999) e Yang J., Yang C. e Kao (2010) que discursam sobre as causas do atrasos de cronograma de obras, suas consequência e perdas para as partes envolvidas. As Parcerias Público Privada, chamadas de PPP, também estão presentes nos trabalhos internacionais sobre obras públicas, como tratam Tang; Shen; Cheng (2010) e Marrewijk et al. (2008). Outros autores, ainda, debatem a questão dos orçamentos das obras, como Magnussen; Olson (2006), Arditi; Akan; Gurdamar (1985), Flyvbjerg; Holm; Buhl (2007).

Para classificar essa grande variedade, Miller e Lessard (2001) propõe que os assuntos sejam divididos em 3 (três) grandes áreas: (1) relacionadas ao assuntos mercadológicos, como demanda, parte financeira e de suprimentos; (2) de realização, que envolve a construção, questões operacionais e técnicas e (3) institucionais, referente à legislação e normas. 
Obras públicas e particulares apresentam algumas peculiaridades próprias quando comparadas entre si. Alguns desses assuntos, como os aspectos construtivos, por exemplo, podem ser aplicáveis tanto em obras executadas pela iniciativa privada quanto pelo Governo sem que qualquer distinção mereça ser levada em consideração. Porém, existem diferentes prioridades em alguns aspectos, necessidades e objetivos diferentes. Provavelmente, as mais relevantes, utilizando a classificação de Miller e Lessard (2001), sejam as questões institucionais, uma vez que as aquisições feitas pelo poder público devem obedecer algumas leis e normas.

Algumas das peculiaridades que diferenciam obras públicas de particulares são citadas por Bretas (2010):

- A lei das licitações impõe alguns procedimentos para a gestão do projeto, o que pode dificultar alguns métodos mais eficientes utilizados na iniciativa privada como projeto simultâneo.

- A importância do projeto no processo licitatório para as obras públicas, principalmente como ferramenta de combate à corrupção,

- Obras públicas normalmente possuem prazos e orçamentos apertados que devem ser respeitados para o cumprimento da Lei Federal 101/2000, a chamada Lei de responsabilidade fiscal.

Assim como toda e qualquer aquisição de material pelos órgãos públicos, a realização de obras deve ser feita através de processo licitatório, uma vez que o Governo não tem condições de manter estrutura que supra todas as demandas de construções de que ele necessita, pois ficaria muito oneroso para a administração pública. 
O artigo 37 da Constituição Federal que fala sobre as aquisições feitas pelos órgãos públicos tem a seguinte redação:

$X X I$ - ressalvados os casos especificados na legislação, as obras, serviços, compras e alienações serão contratados mediante processo de licitação pública que assegure igualdade de condições a todos os concorrentes, com cláusulas que estabeleçam obrigações de pagamento, mantidas as condições efetivas da proposta, nos termos da lei, o qual somente permitirá as exigências de qualificação técnica e econômica indispensáveis à garantia do cumprimento das obrigações. (BRASIL, 1988)

Para que haja um bom entendimento dos termos utilizados nessa pesquisa é importante deixar claro o significado de alguns deles, como o de processo licitatório. De acordo com Mello (1978), ele pode ser definido como sendo:

o procedimento administrativo pelo qual uma pessoa governamental pretendendo alienar, adquirir ou locar bens, realizar obras ou serviços, segundo condições por ela estipuladas previamente, convoca interessados na apresentação de propostas, a fim de selecionar a que se revele mais conveniente em função de parâmetros antecipadamente estabelecidos e divulgados.

De acordo com Cretella Junior (2006), alguns dos princípios que norteiam a lei das licitações são isonomia, legitimidade, impessoalidade, moralidade, igualdade e publicidade.

\subsection{DelimitaÇão do TEMA DA PESQUISA:}

A Lei Federal que regulamenta o processo licitatório é a número 8.666 de 21 de julho de 1.993, chamada lei das licitações. Para a contratação de empresa de engenharia para a execução de obras, 0 artigo $7^{\circ}$ diz o seguinte: 
Art. $7^{\circ}$ As licitações para a execução de obras e para a prestação de serviços obedecerão ao disposto neste artigo e, em particular, à seguinte sequência:

I- projeto básico;

II - projeto executivo;

III - execução das obras e serviços.

$\S 1^{\circ}$ A execução de cada etapa será obrigatoriamente precedida da conclusão e aprovação, pela autoridade competente, dos trabalhos relativos às etapas anteriores, à exceção do projeto executivo, o qual poderá ser desenvolvido concomitantemente com a execução das obras e serviços, desde que também autorizado pela Administração.

$\S 2^{\circ}$ As obras e os serviços somente poderão ser licitados quando:

I - houver projeto básico aprovado pela autoridade competente e disponível para exame dos interessados em participar do processo licitatório;

II - existir orçamento detalhado em planilhas que expressem a composição de todos os seus custos unitários;

II - houver previsão de recursos orçamentários que assegurem o pagamento das obrigações decorrentes de obras ou serviços a serem executados no exercício financeiro em curso, de acordo com o respectivo cronograma; 
Assim, a fase anterior à licitação é caracterizada pelo período de planejamento do empreendimento, no qual são executados projetos, memoriais, orçamentos e cronogramas. Um ponto em que muitos autores concordam trata-se da importância dessa etapa, pois ela tem se mostrado fundamental para a realização de um produto bem sucedido (KOLLTVEIT; GRONHAUG, 2004). Durante essa fase, a principal barreira encontrada é a grande incerteza dos múltiplos pontos que podem influenciar na tomada de decisão por realizar ou não uma obra (KOLLTVEIT; GRONHAUG, 2004). Como ainda caracterizam esses autores, no início pouco se sabe sobre as atividades e sua execução, o que significa que a incerteza está em seu grau máximo, especialmente para projetos com alto grau de novidade.

Vários documentos são elaborados para a licitação. Eles são elaborados para que a execução das obras ocorra dentro do planejamento. Uma informação importante envolvida nessa etapa de decisões é o primeiro orçamento (chamada neste trabalho de orçamento estimado), pois ele é uma das ferramentas responsável pela decisão de realização ou não da obra pelo proprietários, no caso deste estudo, o Governo.

O contrato de prestação de serviços para a realização de uma obra assinado entre o órgão público e a empreiteira classificada em primeiro lugar deverá ser exatamente como foi explicitado no edital de licitação, referente ao projeto com suas especificações, cronograma e orçamento. Normalmente, a empresa considerada vencedora da licitação é a que apresentar menor preço, mesmo sendo permitido por lei outros critérios de escolha. E ainda, a planilha orçamentária apresentada pela empresa vencedora passará pela aprovação dos engenheiros ou arquitetos do órgão público licitante para analisar se, os preços de cada item listados são condizentes com o praticado no mercado. Esta ação é para avaliar se a empresa vencedora consegue, com o valor apresentado, concluir a obra. O processo licitatório termina com a celebração do contrato entre a construtora e o órgão público 


\subsection{Formulação do Problema da PESQUisa:}

Um projeto pode ser considerado de sucesso quando ele consegue alcançar suas metas e seus objetivos estabelecidos previamente através de plano. Isso significa que ele conseguiu cumprir seu desempenho técnico, manter seu cronograma e permanecer dentro do custo orçado inicialmente (FRIMPONG; OLUWOYE; CRAWFORD, 2002). Porém, não é isso que se tem verificado nas obras públicas brasileiras. Problemas fazem com que o contrato assinado entre a empresa vencedora da licitação e o órgão público não possa ser cumprido, seja referente ao custo ou ao orçamento, pois ele não consegue atender às necessidades da obra. Para que não seja necessário outro processo licitatório, a solução legal utilizada é a assinatura de um termo aditivo ao contrato, estendo o prazo ou alterando o valor, podendo ocorrer o aumento ou a diminuição, dentro dos limites estipulados pela Lei Federal 8.666/93.

De acordo com a legislação brasileira, os órgãos públicos podem alterar os contratados celebrados com os vencedores das licitações unilateralmente e somente notificar os outros envolvidos ou então por acordo das partes. (BRASIL, 1993). Essas alterações podem ocorrer para se obter a melhor adequação e técnica a seus objetivos, devidamente justificados, quando (CRETELLA JÚNIOR, 2006):

- Ocorrer modificações de projeto ou das especificações;

- Houver necessidade de alteração do valor contratual, em consequência de acréscimos ou diminuição quantitativa do objeto de contrato, dentro dos limites da lei;

A LF 8.666/93 permite dois tipos de aditivos de contrato: de tempo e de serviço. Aditivos de tempo são solicitados quando se considera que o tempo estipulado para a realização da obra previsto na licitação não será suficiente para o término da obra. Na outra modalidade de aditivo, pode-se pedir a supressões de 
serviços que constam no contrato ou então o acréscimo de algo novo, sempre avaliado a pertinência destes atos pelas duas partes integrantes do contrato. Para ambos os casos, de acréscimo ou de supressão, deverá ser feito o acerto financeiro para que nenhum dos envolvidos tenha prejuízo.

A LF 8.666/93 regulamenta o valor total que pode ser aditivado ao contrato inicial, como mostrado a seguir:

$\S 1$ 10 0 contratado fica obrigado a aceitar, nas mesmas condições contratuais, os acréscimos ou supressões que se fizerem nas obras, serviços ou compras, até $25 \%$ (vinte e cinco por cento) do valor inicial atualizado do contrato, e, no caso particular de reforma de edifício ou de equipamento, até o limite de 50\% (cinquenta por cento) para os seus acréscimos.

Extrapolar o orçamento pode acontecer já na fase chamada de pré-construção, definida pelo período entre a concepção inicial do projeto e a assinatura do contrato de construção entre o proprietário e a empresa contratada para a realização da obra. Por outro lado, alguns problemas podem ocorrer na fase de construção, ou seja, no período entre a assinatura do contrato e a construção propriamente dita (ARDITI, AKAN, GURDAMAR, 1985). Assim sendo, todas as etapas de um empreendimento devem ser bem gerenciadas.

Um dos procedimentos praticados pelas instituições públicas é a utilização do projeto básico para a licitação. Isto é permitido pela LF 8.666/93, porém, o projeto básico utilizado no processo de licitação não possui o mesmo grau de detalhamento do que o descrito pela lei. Como citado pelo engenheiro A, "na maior parte dos casos, utiliza-se, a título de Projeto Básico, estudos preliminares ou anteprojetos ou projetos legais. As especificações são genéricas e os quantitativos são apenas estimados (forma elegante de dizer "chutados")". 
O engenheiro B fala ainda sobre outro problema relacionado aos projetos: "um fato que prejudica a execução é a elaboração dos projetos arquitetônico e complementares dentro do contrato de obra: as contratadas não elaboram os projetos e executam a obra sem aval da fiscalização e sem um projeto que especifique corretamente os serviços a executar".

\subsubsection{PROBLEMA:}

Por que obras públicas, geralmente, necessitam de aditivos de contrato?

\subsection{DeClaração dos objetivos}

O objetivo com esta pesquisa de mestrado é estudar e analisar as ocorrências de aditivos de tempo e de serviço em contratos de obras públicas de equipamentos de educação e saúde. Como contribuição, esta pesquisa propõe um roteiro para análise dos dados de obras públicas dos municípios brasileiros com a finalidade de criar um diagnóstico do comportamento dos contratos dessas obras. Essas análises são aplicadas nos contratos de obras públicas de uma prefeitura municipal.

Dentro desta visão, são analisadas obras públicas de equipamentos de saúde e educação de um município brasileiro. Foram estudados seus processos administrativos, aditivos de contrato (de serviço e de tempo). Esses dados analisados foram comparados aos índices obtidos na literatura encontrada, com a finalidade de diagnosticar a situação da cidade estudada. Outro parâmetro estudado nessa pesquisa é a relação entre os aditivos e a elaboração de projetos para a execução da obra. 


\subsubsection{OBJETIVO ESPECÍFICO:}

Propor roteiro de análises para diagnóstico da situação dos aditivos de contratos de obras públicas.

\subsection{JUSTIFICATIVA}

A iniciativa em realizar esta pesquisa surgiu durante o período de experiência profissional da autora por aproximadamente 3 anos junto a obras públicas, período no qual foram observadas de algumas falhas que ocorriam. Neste período, ao acompanhar o processo de desenvolvimento de obras públicas, desde a sua demanda, passando pela confecção de seu projeto arquitetônico, sua construção e finalmente acompanhando o seu uso, foram identificados alguns erros/ falhas que poderiam ser controlados e evitados. Na tentativa de estudar especificamente a causa de alguns desses erros, nasceu a vontade de realizar uma pesquisa de mestrado, para que, com o auxílio de embasamentos teóricos acadêmicos, algumas causas dos problemas pudessem ser reconhecidas.

Veem-se muitos trabalhos de pesquisa voltados para a gestão de empreendimentos focados na iniciativa privada. Para este tipo de obras, a gama de pesquisas já realizadas é bastante vasta. Podem-se encontrar pesquisas tanto na área tecnológica para aplicação em canteiros de obras quanto para a parte de gerenciamento propriamente dita. Porém, obras públicas possuem características diferentes, pois devem seguir as leis de compra impostas por leis públicas, principalmente a LF 8.666/93, que institui normas para licitações e contratos da Administração pública.

A questão social desta pesquisa também merece ser mencionada. Por buscar melhorias do serviço prestado por órgãos públicos, este trabalho visa dar subsídios para que os agentes públicos possam gerenciar as obras de com mais eficiência, tratando assim, as suas obras com o devido respeito que tais atividades necessitam e 
merecem, principalmente pelo fato de serem verbas públicas. Espera-se que, com a contribuição desta pesquisa somada ao advento de novas, as obras públicas possam alcançar melhores índices de desempenho, tanto nas questões financeiras quanto no tempo de construção, pois o atraso dessas obras causam graves problemas sociais, uma vez que são obras ligadas à saúde e educação.

\subsection{ESTRUTURA DO TEXTO}

Esta dissertação está estruturada em 5 capítulos, referências bibliográficas e anexos. O capítulo 1 inicia com a contextualização da pesquisa, seguida pela delimitação do tema e pela explicação do problema. Apresenta-se também a declaração do objetivo e justificativa da pesquisa.

No capítulo 2, cujo o tema são os aditivos de contrato, são mostradas as principais causas de atrasos de obras públicas e privadas. São também discutidas as causas de aumento de custos e métodos de gestão encontrados como soluções para alguns pontos.

O Capítulo 3 discorre sobre a metodologia utilizada na pesquisa, caracterizando-a. Descreve os procedimentos empregados no estudo de caso, explicitando as fontes de evidencias, as obras escolhidas, seus dados levantados. Apresenta-se ainda o roteiro que foi utilizado para a análise, o qual é proposto a sua repetição em outras repartições públicas.

O Capítulo 4 é focado na interpretação e discussão dos dados obtidos com os da literatura encontrada. São mostradas as análises feitas com os dados levantados na prefeitura municipal estudada e comparados aos dados provenientes da literatura e contextualizar o caso estudo dentro de dados internacionais. 
Finalmente, o capítulo 5 traz as conclusões tiradas sobre o assunto, baseadas na análise e interpretação feita no capítulo anterior. Além da conclusão são deixadas também encaminhamentos de futuras pesquisas consideradas importantes para 0 aprimoramento e aprofundamento das pesquisas em obras públicas brasileiras.

As referencias bibliográficas pesquisadas e utilizadas nesta dissertação encontram-se após o capítulo da conclusão. Encontram-se ainda anexos com diversos documentos, planilhas e questionários utilizados durante a pesquisa. No Anexo I consta o trajeto percorrido para a liberação do acesso aos dados necessários. O Anexo Il mostra a codificação utilizada para a nomenclatura das obras, empregada para garantir o sigilo das obras analisadas. O Anexo III trás a localização dos processos administrativos, mostrando em qual repartição pública os processos estavam quando foram analisados. No Anexo IV é mostrado o formulário que foi utilizado como guia na extração dos dados. Para cada obra analisada, há um respectivo formulário. Foi preenchido um formulário deste por obra analisada. Os anexos V, VI, VII e VIII são as os questionários respondidos pelos engenheiros da prefeitura municipal responsáveis pela fiscalização das construções. Eles foram chamados de engenheiros $A, B, C, D$ e $E$ respectivamente para manter em sigilo as suas identidades. 


\section{ADITIVOS EM CONTRATOS DE OBRAS PÚBLICAS}

\subsection{CONCEITO DE ATRASO EM OBRAS}

De acordo com a definição de Stumpf (2000), atraso é o ato ou o evento que extrapola o tempo requerido para o desempenho de uma tarefa sob um contrato. Uma das preocupações presente nos estudos desta área de conhecimento é a atenção em relação ao atraso das obras. Atrasos de cronograma causam prejuízos para os seus investidores quando se trata de uma obra particular, tanto pelo fato de aumentar o seu próprio custo, quanto pela perda de renda que tal obra geraria pronta (KHALIL, GHAFLY, 1999).

Dentro da literatura, alguns autores propõe uma classificação dos tipos de atrasos que podem ocorrer. Ahmed et al. (2002) criam uma classificação, com quatro categorias, levando em consideração a previsibilidade e a compensação do atraso. São elas:

- Atrasos não desculpáveis: estes atrasos são inerentemente responsabilidade do empreiteiro e nenhuma concessão é permitido, uma vez que o atraso é gerado por falta de responsabilidade do empreiteiro.

- Atrasos desculpáveis não compensáveis: atrasos que não poderiam ser previstos, são causados por motivos inesperados e que fogem ao controle do construtor. $O$ empreiteiro não recebe nenhuma penalização por este atraso, mas também não recebe nenhum pagamento para suprir algum possível prejuízo.

- Atrasos desculpáveis compensáveis: são aqueles causados por motivos que não poderiam ser previstos pelo empreiteiro, geralmente criados por alguma nova reivindicação do proprietário. Neste caso, o 
empreiteiro pode chegar a receber algum acréscimo de pagamento gerado por essa mudança.

- Atrasos simultâneos: Quando a responsabilidade do atraso é tanto do proprietário quanto do empreiteiro. Não há penalizações caso o atraso encaixe-se nessa categoria.

Essa classificação é confirmada pela observação de Palaneeswaran e Kumaraswamy (2008) que diz que alguns atrasos são perdoáveis e até elegíveis, em situações que é preciso optar por novas decisões que afetariam o tempo de obra. Khalil e Gahfly (1999) acrescentam ainda que é irreal acreditar que todas as causas de atraso podem ser evitadas e controladas.

\subsection{CAUSAS DE ATRASOS EM OBRAS PRIVADAS}

De acordo com a Ahmed et al. (2002), os atrasos em projetos na construção são um fenômeno universal, e são geralmente acompanhadas por aumento nos custos. Como citado por Khalil e Ghafly (1999) ambas as partes envolvidas no contrato de construção perdem com os atrasos. O proprietário pela diminuição das receitas potenciais e pelos custos indiretos aumentados provenientes da administração de contratos e supervisão. As consequências para o contratante são geradas pelo aumento dos custos, podendo até deixar de aproveitar oportunidades para novos projetos por causa da diminuição da capacidade financeira.

Atraso, portanto, é uma questão importante para a indústria da construção. Investigações sobre o problema são necessárias a fim de melhor gerir situações de atraso e minimizar as suas consequências. Identificar e estudar alguns pontos relacionados aos atrasos como a frequência de ocorrência, as causas e a responsabilidade podem fornecer informações importantes para melhorar o desempenho do projeto. 


\subsection{CAUSAS DE ATRASOS EM ObRAS PÚBLICAS}

As pesquisas encontradas sobre obras públicas ao redor do mundo possuem variados assuntos. Podem-se citar temas como os métodos para auxiliar as decisões dos administradores públicos, as parcerias entre os órgãos públicos e a iniciativa privada com a finalidade de prestar serviços à população e o critério de seleção dos vencedores de processos de licitação dessas obras públicas, que são decididos, prioritariamente, somente sob a perspectiva da proposta de menor preço. Neste item são explicadas as principais causas de atrasos em obras públicas identificadas na literatura internacional encontrada, sendo os outros temas abordados em outro tópico mais a frente.

De acordo com Elinwa e Joshua (2001), o atraso é comum problema entre projetos de construção. No entanto, parece que projetos do setor público tem a pior condição. Os autores declararam que da totalidade das obras atrasadas, $89 \%$ delas pertencem ao poder público, sendo que, esse número total representa cerca de $80 \%$ a $90 \%$ de toda a construção. E quanto se trata de obras públicas, além desses fatores, o atraso gera mais incômodo e desconforto aos contratantes e aos clientes, no caso, à população (ORANGI; PALANEESWARAM; WILSON, 2011), podendo gerar até problemas sociais.

O debate sobre obras públicas encontra-se muito mais avançado em outros países se comparado ao Brasil, no qual ainda está em um estágio embrionário. Encontram-se mais pesquisas sobre obras públicas até mesmo em países como Nigéria e Angola do que no Brasil, pois nas pesquisas sistemáticas realizadas junto às bases científicas Science Direct, Google acadêmico e Elsevier com palavras chaves de buscas como "public", "public works", "public construction", "bidding", "cost", "cost overruns", "delay" foram encontradas poucas pesquisas cujo país de estudo fosse o Brasil. 
Khalil, Gahfly (1999) estudaram os índices de atrasos de obras públicas de infraestrutura na Arábia Saudita. Em seu estudo, os autores acima citados afirmam que 70\% das obras de água e esgoto da Arábia Saudita atrasam, e esse atraso corresponde a $110 \%$ do cronograma previsto. Ou seja, a maioria desse tipo de obras públicas consomem mais do que o dobro do tempo previsto inicialmente. De acordo com a pesquisa feita por esses autores, os proprietários da obra, no caso o poder público, e os construtores dividem a principal culpa pelos atrasos.

Doloi et al (2012) concluem em sua investigação que, na Índia, um dos fatores mais críticos de atraso na construção é a falta de compromisso. Esta descoberta contradiz os resultados de Razek, Bassioni e Mobarak (2008), no qual os autores consideram que o problema financeiro do contratante é a causa mais importante desses aditivos.

E importante notar o destaque dado à distinção entre países oriundos da pesquisa. O próprio Fallahnejad (2013) lembra que os pesquisadores devem perceber que há diferenças nas condições de cada país que podem causar diferenças e peculiaridades próprias. Fatores como economia, política, cultura, clima, e muitos outros personagens de uma região ou país criam condições específicas que devem ser levadas em consideração.

As causas para esses atrasos são muito variadas como podemos comprovar de acordo com vários autores. Os estudos realizados por Kharashi e Skitmore (2009) com a finalidade de identificar as principais causas de atrasos em obras públicas na Arábia Saudita verificaram que o fator mais influente foi a falta de pessoal qualificado e experiente somada à quantidade considerável de grandes projetos inovadores, associada à pequena oferta de mão de obra.

Assim, devemos pensar no caso brasileiro à luz das suas próprias condições. Acredita-se que as causas dos problemas de gestão de obras públicas brasileiras que geram o aumento de custos e de cronograma estão em etapas anteriores às 
identificadas acima. O que se verifica na gestão de obras públicas é o atropelamento das etapas de projeto de diversas formas, como verificado no artigo de Philippsen Junior e Fabrício (2011). Os autores lembram da importância dos projetos serem bem elaborados em etapas anteriores à obra. Eles lembram também da distinção entre projeto básico e projeto executivo, explicitada pela LF 8.666/93.

Philippsen Junior e Fabrício (2011) mostram alguns dados, da esfera federal brasileira, relacionados à interação observada entre as diversas formações técnicas que compõem uma equipe de projetistas e à relação entre a qualidade dos projetos desenvolvidos e seu impacto durante a execução das obras, passando inclusive por uma possível avaliação pós-ocupação (APO). Os autores identificam as questões relacionadas com a interação entre projetistas, projeto, obra e de acordo com os profissionais do órgão público. Vale destacar o dado que mostra que a frequência de erros ou falhas encontradas nos projetos sendo $42 \%$ frequentemente, $43 \%$ raramente e somente $15 \%$ nunca.

Percebeu-se que, através dos questionários, ou o projeto chega à obra com déficit de informação ou sofre alterações com as obras já em andamento, causando retrabalho. Quando questionados por que licitações abertas somente com projeto básico, a resposta foi que a LF 8.666/93 permite que seja aberto processo licitatório com projeto básico. Porém, ante projetos ou estudos preliminares tem sido nomeado de projeto básico. O Projeto básico, como descrito pela LF 8666/93 no Artigo 6으, para os fins dessa Lei, considera-se:

$I X$ - Projeto Básico - conjunto de elementos necessários e suficientes, com nível de precisão adequado, para caracterizar a obra ou serviço, ou complexo de obras ou serviços objeto da licitação, elaborado com base nas indicações dos estudos técnicos preliminares, que assegurem a viabilidade técnica e $o$ adequado tratamento do impacto ambiental do 
empreendimento, e que possibilite a avaliação do custo da obra e a definição dos métodos e do prazo de execução, devendo conter os seguintes elementos:

a) desenvolvimento da solução escolhida de forma a fornecer visão global da obra e identificar todos os seus elementos constitutivos com clareza;

b) soluções técnicas globais e localizadas, suficientemente detalhadas, de forma a minimizar a necessidade de reformulação ou de variantes durante as fases de elaboração do projeto executivo e de realização das obras e montagem;

c) identificação dos tipos de serviços a executar e de materiais e equipamentos a incorporar à obra, bem como suas especificações que assegurem os melhores resultados para o empreendimento, sem frustrar o caráter competitivo para a sua execução;

d) informações que possibilitem o estudo e a dedução de métodos construtivos, instalações provisórias e condições organizacionais para a obra, sem frustrar o caráter competitivo para a sua execução;

e) subsídios para montagem do plano de licitação e gestão da obra, compreendendo a sua programação, a estratégia de suprimentos, as normas de fiscalização e outros dados necessários em cada caso;

f) orçamento detalhado do custo global da obra, fundamentado em quantitativos de serviços e fornecimentos propriamente avaliados (Brasil, 1930). 
Doloi et al (2012) fizeram uma compilação de causas de aditivos, com o auxílio de outros pesquisadores da área. Os autores classificaram 45 causas de atrasos de obras em 6 categorias, como na tabela a seguir:

Aumento do escopo de trabalho

Ambiguidade nas especificações e interpretação conflitante pelas partes

\begin{tabular}{|c|c|}
\hline \multirow{5}{*}{$\begin{array}{l}\text { Relacionados } \\
\text { ao projeto }\end{array}$} & Relatório de prospecção de solo com erros \\
\hline & Retrabalho devido à mudança de projeto ou pedido de alteração \\
\hline & Cronograma irrealista imposto pelo contratante \\
\hline & Não disponibilidade de projeto à tempo \\
\hline & Retrabalho devido a erros de execução \\
\hline \multirow{9}{*}{$\begin{array}{c}\text { Relacionados } \\
\text { ao local }\end{array}$} & Dificuldade de acesso ao local \\
\hline & Condições meteorológicas extremas \\
\hline & Decisões lentas do proprietário \\
\hline & Atraso na entrega do material pelos fornecedores \\
\hline & Acidentes devido à negligência \\
\hline & Acidentes devido à falta de medidas de segurança \\
\hline & Condições do solo \\
\hline & Condições políticas adversas \\
\hline & Especificação sem precisão das condições do local \\
\hline
\end{tabular}


Atraso no material a ser fornecido pelo proprietário

Atraso na aprovação do trabalho realizado pelo cliente

Relacionados Atraso na aquisição de material pelo contratante

ao processo

Atraso na aprovação dos projetos

Atraso no pagamento do empreiteiro

Atraso na escolha do local

Atraso na aquisição de itens extras

$\mathrm{O}$ armazenamento inadequado de materiais causando perdas

Relutância do arquiteto para a mudança

Gestão e supervisão ruins

Relacionados às pessoas

Conflito entre proprietários e outras partes

Falta de mão de obra qualificada para equipamentos especializados

Má coordenação entre as partes

Dificuldade na obtenção de autorizações

Excesso de burocracia

Relacionado

Estrutura organizacional ruim

às autoridades Mudanças nos regulamentos e nas leis

Falta de controle sobre sub-empreiteiros

Meios falhos de contratação

Tabela 2-2. Causas de atrasos de obras segundo Doloi et al (2012) - continua 


\begin{tabular}{ll}
\hline & Falta de motivação dos empreiteiros em cumprir o cronograma \\
\cline { 2 - 2 } Questões & Mau planejamento durante a fase de licitação \\
\cline { 2 - 2 } técnicas & Restrições financeiras dos empreiteiros \\
\cline { 2 - 2 } & Pouca experiência dos empreiteiros \\
\cline { 2 - 2 } & Aumento de preços dos materiais \\
\cline { 2 - 2 } & Uso ineficiente de equipamentos \\
\cline { 2 - 2 } & O uso de métodos de construção impróprios ou obsoletos \\
\cline { 2 - 2 } & Métodos errados de inspeção e testes propostos em contrato \\
\hline
\end{tabular}

Tabela 2-3. Causas de atrasos de obras segundo Doloi et al (2012) - conclusão

\subsection{QUESTÕES RELATIVAS AOS ORÇAMENTOS}

Segundo Kaliba, Muya e Mumba (2009), o aumento de custos refere-se ao aumento na quantidade de dinheiro necessário para a construção de um projeto e acima o valor original orçado.

Existe um consenso entre esses diversos autores: que é necessário uma maior atenção, cuidado e critério na etapa de elaboração dos orçamentos. O estudo realizado por Magnussen e Olsson (2006) trata de orçamentos e seus aditivos em obras públicas de infraestrutura de transporte no mundo inteiro no período de 1910 a 1998. Segundo os autores, orçamentos bem feitos são importantes, pois desempenham um papel importante nas tomadas de decisões. Eles relatam também que os motivos que causam esses atrasos são variados e difíceis de prever e de gerir. 
As principais causas detectadas por eles são erros fora da área de projeto, no sentido de desgin, como ações do governo, alta de preços e greve.

Ainda segundo Magnussen e Olsson (2006), outro fator que causa aumento do custo estimado são os atrasos, pois os preços dos produtos sobem. Somado a isso, ainda existe o fato de muitos itens serem esquecidos ou omitidos da planilha orçamentária, que também causam aditivos nos contratos, fato este que os autores consideram incompetência.

Existe também como causa de aumento do custo da obra alterações de projeto, ou seja, mudança do seu escopo. Essas alterações podem possuir diversas causas, como mudança da demanda no meio do processo e falha no levantamento de necessidades no inicio.

Flyvbjerg; Bruzelius; Rothengatter (2003) e Flyvbjerg; Holm; Buhl (2007) acreditam que erros de orçamento nesse tipo de obra são gerados propositalmente, com a finalidade de enganar as partes interessadas sobre os verdadeiros custos da obra. Interessados em descobrir o porquê das grandes diferenças de custo real e custo estimado em obras de infraestrutura de transporte, os pesquisadores analisaram obras do ramo. De acordo com a metodologia aplicada por eles, estudaram um grande número de obras, em diferentes lugares, com diferentes tipos de projetos e diferentes períodos históricos.

A importância do primeiro orçamento de uma obra é grande, pois é em cima desse dado que ocorre a tomada de decisão sobre a realização ou não do projeto. Assim, segundo Flyvbjerg; Holm; Buhl (2007), alguns itens podem ser omitidos intencionalmente desse orçamento inicial para que o projeto possa continuar vivo, como ignorar ou desvalorizar riscos geológicos, questões ambientais ou de segurança. Esses autores demonstram que, de acordo com estatísticas obtidas através de suas pesquisas, em $86 \%$ das obras pesquisadas o custo real é maior do que a primeira 
estimativa, complementado pelos outros $14 \%$ que tiveram seus orçamentos reais abaixo do estimado.

Flyvbjerg; Holm; Buhl (2007) acreditam que os erros deveriam diminuir com o tempo, pois aumentaria a experiência e os métodos estariam mais apurados. Porém concluiram que os erros de orçamento possuem a mesma magnitude de 10, 30 ou 70 anos atrás da pesquisa realizada por eles. Os dados mostram que as habilidades para a estimativa e previsão de custos de projetos de infraestrutura de transporte não têm melhorado ao longo do tempo. Aprendizagem não parece ocorrer neste setor importante para a sociedade e altamente custosa de tomadas de decisões tanto para a iniciativa pública. De acordo com os autores, este comportamento parece não habitual e abre precedentes para a especulação de que a persistência desta prática, independente do tempo histórico, localização e tipo de projeto, de subestimação de custos significativa e generalizada é um sinal de que um equilíbrio foi alcançado: fortes incentivos e desincentivos fracos para a subestimação pode ter ensinado os promotores de projetos a subestimação de custos compensa. Se este for o caso, a subestimação deve ser esperada e ainda deve ser considerada intencional (FLYVBJERG; HOLM; BUHL, 2007).

Flybjerg; Holm; Buhl (2007) mostram dados falando que 85\%, ou seja, quase 9 em 10 projetos, na Noruega, de infraestrutura de transporte possuem seu preço reajustado e esse reajuste varia em média $28 \%$. Os mesmos autores se questionaram se esse grande número de aditivos é causado realmente por erros ou por outros motivos. Para chegar a essa conclusão, eles analisaram três tipos diferentes de obras de transporte: ferrovias, rodovias e pontes e viadutos. Os autores detectaram quatro fontes para esse erro: a explicação técnica, a psicológica, a econômica e a política. A principal conclusão tirada dessa pesquisa é que os erros de orçamentos são feitos propositalmente. 
Outra conclusão que os autores acima chegaram foi que devido à grande amplitude de países estudados na sua pesquisa, localizados na América do Norte e Europa, eles puderam concluir que subestimar o valor das obras de transporte é uma prática generalizada. Porém, nenhum país em desenvolvimento foi estudado, e como já dito, as causas desses aditivos variam entre os países de acordo com suas peculiaridades próprias.

Arditi; Akan; Gurdamar (1985), em seu estudo sobre obras que tiveram seus orçamentos extrapolados na Turquia, entre as décadas de 1970 e 1980 identificaram 14 motivos: aumento dos preços dos materiais, inflação, dificuldades na obtenção de materiais de construção em preços competitivos, atrasos na construção, deficiências nas estimativas de custos elaborados por órgãos públicos, aumento de salários de funcionários, inesperadas condições do subsolo, deficiências na infraestrutura, problemas do trabalho, problemas de seguros, deficiências na estrutura social, problemas relacionados com o trabalho de segurança, problemas relacionados à saúde dos trabalhadores, outros.

Em decorrência dos atrasos, os custos sofrem aumento, devido ao reajuste de preço dos materiais com o passar do tempo os custos dos equipamentos, materiais e mão-de-obra sobem, onerando assim, o orçamento inicial. Khalil, Gahfly (1999) exemplificam esse dado, ao estudarem os índices de atrasos de obras públicas de infraestrutura na Arábia Saudita.

\subsection{MÉTOdOS DE GESTÃo UTILIZADOS}

Vários métodos gerenciais são estudados na tentativa melhorar a gestão de obras, tentando amenizar as possibilidades de prejuízos causados pelo atraso, pela necessidade de aditivos de prazo e/ou de serviços, pela demora na liberação de 
documentação por outros órgãos públicos envolvidos, entre outros enclaves que podem ocorrer durante a construção.

Inserido nessa ampla discussão de obras públicas, Abbasi e Mharmah (2000) discursam sobre a implementação de melhoramentos nos procedimentos gerenciais baseados nas teorias do Project Management Institute (PMI) nos conceitos de gestão de projetos completos, desde a fase inicial de planejamento, passando pela programação de tempo, custo e recursos, em seguida, terminando com a fase de controle até que o projeto é realizado.

Outra ferramenta desenvolvida é a criada por Saaty (1990) para auxiliar nas tomadas de decisões quando diversos fatores a influenciam. Chamado de AHP, Analytical Hierarchy Process, este procedimento consiste na ponderação e pareamento dos parâmetros envolvidos sobre determinado assunto. Esta análise é feita em três etapas: após a criação de uma árvore hierárquica, pesos e valores são atribuídos para cada item e, após a ponderação desses itens, obtem-se subsídios para a tomada de decisão. Essa ferramenta também pode ser utilizada em diversas formas para a construção civil como ilustrado por diversos autores como Khalil (2002), Khalil, Braglia e Carmignani (2006), Lai, Wang, W. e Wang, H. (2008), Puthamont e Charoenngam (2007) entre outros.

Baseado no AHP, Khalil (2002) discursa sobre como escolher o melhor método de contratação empresas para a realização de obra pública levando em consideração três categorias: (1) características do projeto, (2) necessidades e (3) preferencias do proprietário, na qual, para cada item alocado sob uma dessas categorias possui um peso que, após a ponderação determina qual o melhor método para a realização da obra.

Lin, Wang e Yu (2008) acrescentam ainda que o método AHP tem limitações. À medida que aumenta o número de parâmetros, devido ao seu pareamento de critérios e atribuição de valores para cada item, a capacidade do ser humano para expressar 
com precisão o seu conhecimento diminui com a complexidade crescente do problema. Assim, como o aumento do número de critérios para a análise, os consultores ficam susceptíveis a fazer julgamentos mais inconsistentes durante essa comparação de pares. Em virtude disto, é proposto que essa analise seja feita através de algoritmos, uma vez que a escala Saaty é composta de números inteiros de 1 a 9, a escala "fuzzy", batizando o método de Adaptive AHP Approach $\left(A^{3}\right)$.

O estudo acima citado encontra-se na mesma linha de pesquisa do realizado por Hsieh, Lu e Tzeng (2004), pois também trata de propor alternativas para a licitação de edificações públicas de Taiwan, utilizando a escala "fuzzy". Nele são apresentados uma série de índices, números e gráficos para a ponderação dos interesses de diferentes atores envolvidos na construção de uma delegacia de polícia de Taipei. De acordo com os resultados pode-se optar pela melhor forma de execução deste projeto.

Muitas críticas são feitas ao modelo existente. As várias críticas tecidas à LF n8.666/93, pode-se citar Dallari (1994) sobre as deficiências características da referida lei:

Em decorrência de uma orientação totalmente equivocada, tendo optado pelo caminho evidentemente insensato de procurar dar solução para as inúmeras e infinitas questões que podem aparecer nas licitações e nos contratos, que acabou por se perder num detalhismo que leva, inevitavelmente, a contradições $e$ impropriedades, passando por disposições inúteis e incompreensíveis, tudo isso servindo para empecer o andamento das ações administrativas e para fomentar conflitos.

Mesmo a lei possibilitando que o vencedor da licitação pública seja determinado pela melhor técnica, a prática o que se observa, na grande esmagadora maioria das vezes, é a escolha ser baseada somente em um critério, o preço, atitude essa, que será debatida por pesquisadores ao redor do mundo, que pregam que se 
deve levar em consideração múltiplos critérios para a seleção da proposta vencedora como Seydel e Olson (2001).

De acordo com Khalil (2002), uma crítica pertinente ao procedimento de construção de obras públicas é o fato de ela ocorrer, praticamente exclusivamente, no método sequencial de projeto-licitação-construção, o DBB (design-bid-build), quando há outras possibilidades como o DB (design-build) e o CM (construction manager). Este método, o mais tradicional e comum, exige o gerenciamento do proprietário do projeto (órgão público, no caso), mas também é famoso pelos conflitos existentes entre as partes envolvidas. 


\section{MÉTODO DE PESQUISA}

O estudo de caso unitário foi o método de pesquisa utilizado nesta pesquisa, pois além de possuir foco em fenômenos contemporâneos da vida real (Yin, 2005), busca-se descobrir o porquê da ocorrência de elevado número de aditivos de contratos.

\section{Fontes de Evidências}

\begin{tabular}{|c|c|c|}
\hline Fonte & Data & Dados \\
\hline $\begin{array}{l}\text { Página } \\
\text { eletrônica }\end{array}$ & Nov/2011 & $\begin{array}{l}\text { Levantamento dos editais das licitações abertas, nos } \\
\text { quais conta o numero do processo de cada licitação. } \\
\text { Foram visitados para a pesquisa nos seguintes links: } \\
\text { Licitações do FMS, nas categorias: } \\
\text { Convite de preço. Anos 2007, } 2008 \\
\text { Tomada de preço. Anos 2006, 2007, } 2008 \\
\text { Licitações da PM, nas categorias: } \\
\text { Concorrência Pública. Anos 2006, 2007, 2008, } 2009 \\
2010 . \\
\text { Convite de Preço. Anos 2006, 2007, 2008, 2009, } 2010 \\
\text { Tomada de preço. Anos 2006, 2007, 2008, 2009, } 2010\end{array}$ \\
\hline $\begin{array}{c}\text { Processos } \\
\text { administrativos }\end{array}$ & $\begin{array}{l}\text { Mai/ Jun } \\
2012\end{array}$ & $\begin{array}{l}\text { Levantamento de dados dos processos, de acordo com } \\
\text { o formulário no anexo III, para a análise. Os processos } \\
\text { estavam em } 4 \text { repartições públicas: SMOP, SMS, } \\
\text { Expediente e autarquia de patrimônio histórico. }\end{array}$ \\
\hline Diário Oficial & $\begin{array}{l}\text { Mai/ Jun } \\
2012\end{array}$ & $\begin{array}{l}\text { Foram consultados para ratificar a assinatura dos } \\
\text { contratos entre a PM e as empreiteiras, uma vez que é } \\
\text { obrigatória a publicação dos contratos assinados pela } \\
\text { PM. }\end{array}$ \\
\hline Questionários & Ago/2012 & $\begin{array}{l}\text { Foi enviado via email um questionário com questões } \\
\text { abertas para os funcionários da SMOP para consultar } \\
\text { as suas impressões sobre o gerenciamento das obras } \\
\text { públicas. }\end{array}$ \\
\hline
\end{tabular}




\subsection{DESCRIÇÃO do ESTUdO DE CASO}

Neste item estão mostradas as fontes de evidencias utilizadas. Para ilustrar essas análises, foi estudado o caso de uma prefeitura municipal. Neste capítulo serão tratadas as etapas.

\subsubsection{FONTES DE EVIDENCIAS}

Esta tabela traz a síntese das fontes de evidencias utilizadas nesta pesquisa de mestrado. O estudo de caso foi realizado em uma prefeitura municipal do interior paulista com aproximadamente 200 mil habitantes pelo censo de 2010. Como primeira fonte de dados, foi utilizada página eletrônica da prefeitura estudada. Como as licitações precisam ser divulgadas em veículos de comunicação, um desses veículos utilizados, além do diário oficial do município e jornais impressos, é a pagina eletrônica da prefeitura. Nela, existe um link no qual são tratados os assuntos pertinentes às licitações abertas, como a divulgação dos editais abertos, as perguntas e respostas sobre dúvidas dos editais e outras informações necessárias. Foi nesse link onde foram selecionadas as obras analisadas. Foram analisados os editais pertencentes ao Fundo Municipal de Saúde (FMS), nas categorias de Convite de preço, referente aos anos de 2007 e 2008 e as tomadas de preços realizadas em 2006, 2007 e 2008. Nas licitações abertas pela prefeitura, as categorias que se encaixavam no recorte desta pesquisa foram as concorrências públicas dos anos 2006, 2007, 2008, 2009 e 2010, os convite de preços dos anos 2006, 2007, 2008, 2009 e 2010 e as tomadas de preços abertas também no período compreendido entre 2006 e 2010.

Nesses editais, consta o número do processo pelo qual tramita toda a documentação referente à licitação e à obra, é onde documentos, projetos, orçamentos, pareceres, contratos e todas as informações pertencentes ao processo encontram-se. Assim, os processos podem ser considerados como a principal fonte de dados desta pesquisa. 
Os processos analisados encontravam-se distribuídos por quatro repartições da prefeitura, a secretaria de obras públicas, a secretaria de saúde, a autarquia de patrimônio histórico e o departamento de expediente da secretaria de administração pública. A localização de cada um pode ser vista no Anexo II desta pesquisa.

\subsubsection{LEVANTAMENTO DAS OBRAS}

Inicialmente, foi realizada uma primeira seleção de obras, através de dados obtidos com os funcionários da SMOP e da Secretaria Municipal de Educação, SME. Porém, esses dados foram descartados. Preferiu-se utilizar, como fonte de escolha de obras um dos veículos de comunicação utilizado pela prefeitura municipal para divulgar suas licitações, o site da própria prefeitura. Assim, as obras escolhidas teriam passado pelo processo completo de licitação. Esta pesquisa não é focada no estudo da licitação, porém acredita-se ser importante que o processo completo tenha sido empregado.

Das possíveis fontes de informações de um estudo de caso, nesta pesquisa foi utilizado o site oficial da Prefeitura Municipal. Ele tornou-se a única fonte de obtenção das licitações abertas. Como constam da página oficial todas as obras licitadas a partir de 2006, uma vez que um dos princípios da LF 8.666/93 é a comunicação da sua abertura. É nessa fonte que se encontra o número do processo administrativo, no qual ficam guardadas todas as informações referentes a esta licitação. Assim, foram

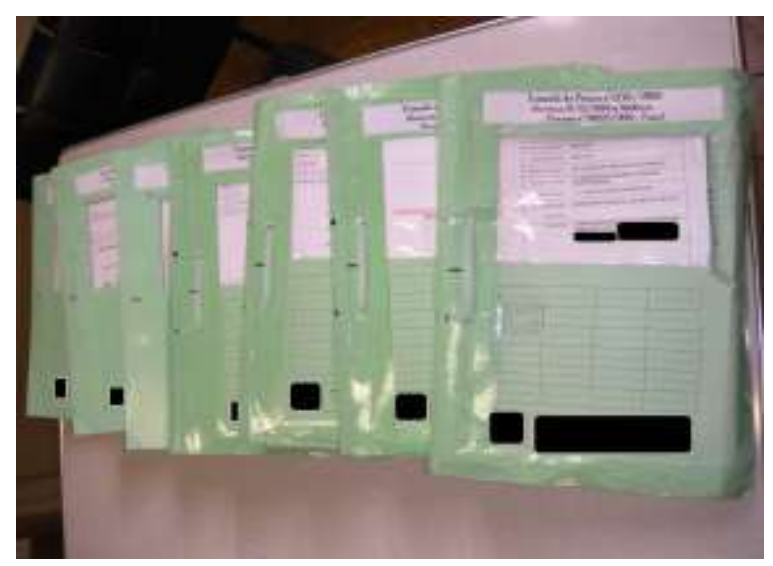

Figura 3-1. Foto ilustrativa dos processos analisados. Fonte: autora 
selecionadas 34 obras divididas entre 12 obras de saúde e 22 de educação. Para garantir o sigilo das obras estudadas, foi criado um sistema de codificação dos processos para identificá-las.

Deste levantamento obteve-se a tabela abaixo como o conjunto resultante de obras que foram analisadas:

Saúde

\begin{tabular}{ccc}
\hline SA.AM.SA.SAM.07 & SA.CO.HO.PAN.08 & SA.AM.BS.IBE.09 \\
SA.CO.SF.SUL.07 & SA.AM.BS.LAH.10 & SA.CO.HO.PAN.07 \\
SA.AM.BS.CRE.09 & SA.CO.SF.ARA.10 & SA.CO.BS.OZO.08 \\
SA.CO.PA.PRA.07 & SA.AM.SAM.SAM.07 & SA.CO.HO.PAN.08 \\
\hline
\end{tabular}

Tabela 3-2. Lista de obras levantadas de equipamentos de saúde

Educação

\begin{tabular}{lll}
\hline ED.AM.BA.GAL.07 & ED.AM.IN.TOB.09 & ED.AM.IN.DAR.09 \\
ED.CO.IN.BEN.09 & ED.AM.IN.SER.08 & ED.CO.IN.COT.10 \\
ED.AM.IN.OCT.09 & ED.CO.IN.PER.09 & ED.AM.IN.MAR.09 \\
ED.CO.IN.BLA.10 & ED.AM.BA.GAL.09 & ED.CO.IN.BOT.09 \\
ED.AM.IN.KEP.08 & ED.CO.IN.ITA.10 & ED.AM.IN.KEP.06 \\
ED.CO.IN.FEL.10 & ED.AM.IN.MON.08 & ED.CO.IN.FRE.10 \\
ED.AM.IN.CAS.09 & ED.CO.IN.OLI.10 & ED.AM.IN.DER.10 \\
ED.CO.IN.NOV.10 & & \\
\hline
\end{tabular}

Tabela 3-3. Lista de obras levantadas de equipamentos de educação 
O código possui 5 campos, todos separados por pontos, divididos da seguinte forma: o primeiro campo, composto por duas letras, que servem para identificar se a obra é de saúde ou de educação, SA para aquele tipo de edificação e ED para este tipo, como mostra no anexo II. Após essa classificação, o código mostra um campo formado por duas letras, que correspondem ao tipo de obra, sendo AM para obras de ampliação ou CO para a construção de nova edificação, de acordo o anexo II.

A próxima sigla de identificação é sobre o uso da edificação composta de duas letras. Essa parte da codificação pode ser referente a escolas de ensino infantil ou básico, hospital, posto de saúde da família, unidades de pronto atendimento, entre outros como ilustrado na tabela. A quarta parte do código é composta por 3 letras, que remetem ao nome da edificação, podendo ser as suas inicias ou alguma abreviatura, sem que seja explicitada por completo a edificação. A quinta e última parte consiste em 2 números, referente aos dois últimos dígitos do ano em que o processo foi aberto para a realização da obra. Como citado, os anos estudos são 2006, 2007, 2008, 2009 e 2010.

\subsubsection{LOCALIZAÇÃO DOS PROCESSOS}

Após o conhecimento de quais processos seriam estudados, o próximo passo foi saber onde eles estavam, em qual repartição da prefeitura municipal ele estava. Assim, o sistema de documentação de processos da prefeitura municipal, o Gerenciador Integrado de Administração Pública, (GIAP) foi consultado. De posse do número do processo, o GIAP fornecia a localização, entre outras informações. Como a PM não permitiu o acesso a esse sistema, essa busca foi realizada pelos próprios funcionários da SMOP. Como alguns processos ainda não tinham sido arquivados enquanto que outros já, os processos encontravam-se em diversos setores dentro da prefeitura municipal. Pode-se listar a secretaria de obras públicas (SMOP), a secretaria municipal de saúde (SMS), a autarquia responsável pelo patrimônio histórico da cidade, nesta tabela chamada de PAT, o departamento de protocolo e arquivo (DPA), a 
seção de expediente, abreviada para EXP. A localização dos processos ocorreu de acordo com a tabela exibida no Anexo III.

\subsubsection{QUANTO AO TIPO DE EQUIPAMENTOS}

Foram escolhidas obras de edificação para equipamentos públicos municipais da área de Saúde e Educação, pois os investimentos nessas áreas possuem "recurso carimbado" como é chamado. Isso quer dizer que a própria Constituição Federal Brasileira determina, por lei, a porcentagem que cada município deve investir da sua arrecadação em Saúde e Educação, obrigatoriamente, sendo que estava verba não pode ser utilizada para outros usos. Caso o prefeito não destine a porcentagem mínima exigida por lei para estes fins, pode ser processado por improbidade administrativa, perder o cargo e ser preso. Deste modo, todos os municípios da União são obrigados a investir tais montantes de verba nessas áreas, sendo que é permitido o uso destes recursos para a construção de obras de edificações para atender às demandas da população. Deste modo, pode-se concluir que, a escolha das obras pertencentes à Educação e à Saúde torna-se muito pertinente na medida em que todos os 5.561 municípios brasileiros são obrigados a investir parte da sua renda nessas áreas.

No caso da Educação, é a própria Constituição Federal que determina este valor, através do Artigo 212 do Capítulo III - da Educação, da Cultura e do Desporto Seção I - da Educação:

Art. 212 - A União aplicará, anualmente, nunca menos de dezoito, e os Estados, o Distrito Federal e os Municípios vinte e cinco por cento, no mínimo, da receita resultante de impostos, compreendida a proveniente de transferências, na manutenção e desenvolvimento do ensino (BRASIL, 1988) 
A cidade estudada, o repasse de verbas para a Educação é de $27 \%$, 2\% a mais do que diz a Constituição Federal. Segundo o Art. 211 também da Constituição Federal, $C F$, “os Municípios atuarão prioritariamente no ensino fundamental e na educação infantil" (BRASIL, 1988). Assim, as obras que serão analisadas na área da Educação serão os CEMEls (Centro Municipal de Educação Infantil), as EMEBs (Escola Municipal de Ensino Básico), as creches e outras obras realizadas que foram encontradas no levantamento realizado junto aos órgãos competentes. No caso da Educação, as quadras poliesportivas construídas em algumas escolas também serão analisadas devido a grande recorrência deste tipo de obra que foram encontradas no período estudado.

No caso da Saúde, o montante de investimentos que cada município deve repassar é descrito na Lei de Diretrizes Orçamentárias do ano vigente, a LDO. No texto da LDO aprovado em 2010, referente a 2011, diz que o valor a ser aplicado na Saúde no deve seguir a Emenda Constitucional $n^{\circ} 29$, que está vigente desde 2003. Essa emenda obrigada cada município, a partir de 2004, a investir no mínimo $15 \%$ de sua receita vinculada em saúde. A cidade estudada investe, nessa área, $21 \%$ do seu arrecadamento, ou seja, $6 \%$ a mais do que o Governo Federal determina. Este trabalho, no caso das obras para a Saúde, irá ater-se às edificações do Programa de Saúde da Família, (PSF), às Unidade Básica de Saúde (UBS) e às Unidades de Pronto Atendimento (UPA), entre outras intervenções que forem julgadas pertinentes.

Assim, encontramos entre as principais obras estudadas, no âmbito da Educação, os exemplares de CEMEls, EMEBs, creches, quadras poliesportivas construídas nas escolas, em relação às obras da Saúde pode-se citar USF, UBS UPA e algumas etapas de Hospital.

\subsubsection{QUANTO AO TIPO DE OBRA}

Somado aos parâmetros explicados anteriormente, foram estudadas obras de construção de novas unidades e de ampliação, ficando excluídas desta pesquisa as obras de reformas das edificações. Entende-se que obras de reformas também 
merecem uma pesquisa somente para si, devido ao grande número de fatores surpresas que podem aparecer no decorrer da obra. A própria LF 8.666/93reconhece essa diferença entre uma obra nova/ampliação e reforma, uma vez que permite até $25 \%$ de aditamento para obras novas e até $50 \%$ para reformas. Neste estudo, são analisadas obras somente com até $25 \%$.

O início será com a abertura do processo para o controle da obra em questão pela SMOP. O seu final se dará com o termo de aceite da obra que caracteriza o final da obra. Assim, todo o procedimento envolvendo a obra em questão estará disponível para levantamento de dados. Porém, o recorte principal da pesquisa será a elaboração da planilha orçamentária e os aditivos que possivelmente poderão aparecer posteriormente. A abertura de acessibilidade de dados para todo o processo permitirá obter as informações necessárias para concluir a análise da pesquisa. Entre esses dados além do tipo de edificação que será estudada pode-se saber a partir de qual etapa do processo de elaboração de projeto foi aberta a licitação, qual foi a entidade de fomento da obra, qual o valor da sua planilha orçamentária utilizada no edital da licitação, qual a quantia da proposta vencedora da licitação, se houve necessidade de aditivo, quem o solicitou, qual a sua justificativa, de onde veio a verba para complementar a obra, em quanto tempo ocorreu a obra e outras informações pertinentes que aparecem no processo.

Porém, o processo licitatório para contratação da empresa ficará de fora desta pesquisa, pois se acredita que este procedimento mereça uma pesquisa inteira para si, devido à grande complexidade deste processo, com todas as suas normas e leis que devem ser obedecidas.

Com o andamento da pesquisa, a leitura de algumas referências encontradas e umas seções de debate, foi decidido mudar o objeto de estudo de caso, resultando na pesquisa descrita nesta qualificação. Assim, pode-se concluir que o lapso temporal existente entre a liberação e o início da pesquisa se deu devido a este fato. 
Além do recorte sobre o uso dos equipamentos públicos, tem-se o referente à questão temporal. Após conversas com os funcionários da secretaria de obras públicas, optou-se por estudar obras licitadas entre 2006 e 2010, pois as obras deste período possuem o maior número de informações disponíveis para o levantamento de dados para subsidiar a análise e conclusão desta pesquisa. É também a partir deste ano, as licitações passaram a ser anunciadas também no site da prefeitura. Assim, devido a disponibilidade dos dados, confirmou-se o recorte temporal sendo pelas obras licitadas entre 2006 e 2010.

\subsection{Proposta de Roteiro de coleta e ANÁlise}

Nesse item foram relatados os procedimentos utilizados para a análise das obras públicas. Esses são os procedimentos sugeridos como um roteiro para a criação do diagnóstico sobre o comportamento desses contratos.

Os passos para a análise seguiram o seguinte planejamento:

1. Selecionar as obras a serem analisadas.

2. Extrair dados pertinentes.

3. Tabelar os dados.

4. Calcular médias e relações.

5. Analisar os dados trabalhados.

\subsubsection{SELECIONAR AS OBRAS}

No caso desta pesquisa, as obras escolhidas para a análise foram as relacionadas à Saúde e Educação, como dito anteriormente. Porém, há a possibilidade 
de outros tipos de obras serem analisadas também. Podem-se utilizar obras viárias, de infraestrutura, de edificações, obras urbanísticas ou quaisquer que possam interessar serem estudadas. Ou seja, é neste ponto que ocorre a seleção de obras trata-se especificamente de quais obras serão analisadas, propriamente dito.

\subsubsection{EXTRAIR OS DADOS}

As informações que foram extraídas dos processos são as seguintes:

- Número do processo: número que tramita o processo.

- Número de volumes: Quantos volumes existem no processo.

- Número da licitação: o numero que identifica esse processo licitatório

- O valor da planilha orçamentária (custo estimado): o valor orçado pela PM e encaminhado para a licitação.

- Tempo previsto de obras: o estimado pelo órgão público

- Modalidade de licitação: qual a modalidade utilizada para a licitação. Pode variar entre Carta Convite, Tomada de preço ou Concorrência Pública, dependendo do valor da obra.

- Projeto enviado para licitação: Qual grau de detalhamento que foi enviado para a licitação. Listado todos os projetos desenvolvidos para a obra. Os projetos listados aqui são terraplenagem, arquitetura básico, arquitetura executivo, fundações, instalações água fria, instalação de esgoto, instalações elétricas e telefonia, estrutura, drenagem águas pluviais, prevenção e combate a incêndio, ar condicionado, sistema de proteção de descargas atmosféricas, instalação de gás e ventilação mecânica.

- Número de pranchas: quantidade de pranchas de cada projeto citado no item anterior.

- Projeto desenvolvido por: profissional que desenvolveu o projeto.

- Valor da proposta vencedora: Qual o montante de dinheiro com o qual a empresa vencedora da licitação se propõe em construir o empreendimento em questão. 
- Empresa vencedora: O nome da empresa que ofereceu a melhor proposta.

- Nome da obra: Neste estudo elas tiveram seu nome alterado por um código para manter o sigilo

- Ano: da abertura da licitação

- Data de início da obra: Caracterizada pela emissão da ordem de serviço pela secretaria de obras permitindo o inicio das obras.

- Data de término da obra: caracterizado pelo documento emitido pela secretaria dando o aceite da obra.

- Necessidade de aditivo: Este campo também será preenchido com Sim ou Não, para ser desmembrado nos próximos campos.

- Quantidade de aditivos: Será descrita a quantidade de aditivos que ocorreram durante a obra. A partir deste ponto, caso haja mais de um, haverá uma linha de preenchimento na tabela para cada aditivo.

- Data: Quando foi assinado o termo aditivo.

- Tipo de aditivo: Como existem dois tipos de aditivos: de tempo e de serviço, este campo será preenchido de acordo com o tipo, mostrando se houve aditivo somente de tempo, somente de serviço, ou de ambos.

- Valor do aditivo: preenchido com o valor numérico do aditivo.

- Unidade de medida do aditivo: Dias ou de reais, dependendo do tipo de aditivo (tempo ou serviço).

Após o preenchimento de um formulário desses para cada obra, mostrado no Anexo IV, o próximo passo é a confecção de uma tabela única. Além dos dados obtidos nos processos, nessa planilha já aparecerem as primeiras análises, como algumas porcentagens. O Cabeçalho desta tabela está transcrito abaixo separado em 4 partes e possui uma obra fictícia para ilustrar o seu preenchimento. 


\subsubsection{TABELAR OS DADOS}

Após a seleção de quais obras foram analisadas, a próxima etapa da análise é a extração os dados utilizados. Para facilitar, orientar e padronizar, foi criado um formulário, ilustrado no Anexo IV, esse levantamento. Os dados levantados foram:

\begin{tabular}{cccccccc} 
Nome & Ano & $\begin{array}{c}\mathbf{N}^{\circ} \\
\text { processo }\end{array}$ & $\begin{array}{c}\text { no. } \\
\text { Volumes }\end{array}$ & $\begin{array}{c}\mathbf{N}^{\circ} \\
\text { Licitação }\end{array}$ & Valor Estimado & $\begin{array}{c}\text { Tempo } \\
\text { previsto } \\
\text { de Obra }\end{array}$ & $\begin{array}{c}\text { Tipo de } \\
\text { Licitação }\end{array}$ \\
\hline Escola & 2008 & $\begin{array}{c}12.345 / \\
2008\end{array}$ & 6 & $01 / 2008$ & $\mathrm{R} \$ 1.100,00$ & 365 & $\begin{array}{c}\text { Carta } \\
\text { Convite }\end{array}$ \\
\hline
\end{tabular}

Tabela 3-4. Exemplo da tabela totalizadora de obras (continua)

\begin{tabular}{cccccc}
$\begin{array}{c}\text { Total aditivo } \\
\text { tempo }\end{array}$ & $\begin{array}{c}\text { Valor Total } \\
\text { Final }\end{array}$ & $\begin{array}{c}\text { Tempo Total } \\
\text { Final (em dias) }\end{array}$ & $\begin{array}{c}\% \text { de } \\
\text { aumento de } \\
\text { valor }\end{array}$ & $\begin{array}{c}\% \text { de } \\
\text { diferença de } \\
\text { tempo }\end{array}$ & $\begin{array}{c}\text { Total de } \\
\text { pranchas }\end{array}$ \\
\hline 365 & $\mathrm{R} \$ 1.250,00$ & 730 & $25 \%$ & $100 \%$ & 27 \\
\hline
\end{tabular}

Tabela 3-5 - (continuação) exemplo da tabela totalizadora de obras (continua)

\begin{tabular}{|c|c|c|c|c|c|}
\hline $\begin{array}{l}\text { Projeto para } \\
\text { licitação }\end{array}$ & $\begin{array}{l}\text { Numero } \\
\text { de } \\
\text { pranchas }\end{array}$ & $\begin{array}{c}\text { Projeto } \\
\text { desenvolvido } \\
\text { por }\end{array}$ & $\begin{array}{l}\text { Valor da } \\
\text { proposta } \\
\text { vencedora }\end{array}$ & Início obra & $\begin{array}{l}\text { Final da } \\
\text { obra }\end{array}$ \\
\hline Arq. executivo & 15 & $\begin{array}{l}\text { Arquitetos e } \\
\text { engenheiros } \\
\text { associados }\end{array}$ & $\mathrm{R} \$ 1.000,00$ & 01/01/2009 & 01/01/2011 \\
\hline Estrutura & 10 & & & & \\
\hline
\end{tabular}

Tabela 3-6 - (continuação) exemplo de tabela totalizadora de obras (continua) 


\begin{tabular}{ccccccc}
$\begin{array}{c}\text { Necessidade } \\
\text { de aditivo }\end{array}$ & $\begin{array}{c}\text { Qdade de } \\
\text { aditivos }\end{array}$ & Data aditivo & $\begin{array}{c}\text { Tipos de } \\
\text { aditivos }\end{array}$ & $\begin{array}{c}\text { Valor } \\
\text { aditivo }\end{array}$ & $\begin{array}{c}\text { Unidade de } \\
\text { medida do } \\
\text { aditivo }\end{array}$ & $\begin{array}{c}\text { Total } \\
\text { aditivo } \\
\text { serviço }\end{array}$ \\
\hline Sim & 1 & $01 / 01 / 2010$ & Serviço & 150 & Reais & $\mathrm{R} \$ 250,00$ \\
& 2 & $01 / 01 / 2010$ & Tempo & 180 & Dias & \\
& 3 & $01 / 06 / 2010$ & Tempo & 90 & Dias & \\
& 4 & $01 / 09 / 2010$ & Serviço & 100 & Reais & \\
& 5 & $01 / 09 / 2010$ & Tempo & 90 & dias & \\
\hline
\end{tabular}

Tabela 3-7 - (continuação) exemplo de tabela totalizadora de obras (conclusão)

\subsubsection{CALCULAR AS MÉDIAS E RELAÇÕES}

A partir dos dados dessa tabela foi possível fazer os seguintes cálculos para subsidiar as discussões:

Porcentagem de obras sem aditivos

Porcentagem de obras que foram construídas sem precisar de qualquer

aditivo. A meta ideal seria que esse número fosse $100 \%$, porém como visto pelos artigos, isso é um patamar ilusório.

Porcentagem de obras que tenham aditivo só de serviço

Valor da porcentagem de obras que conseguiram cumprir o cronograma, porém, não conseguiram cumprir o orçamento. São as obras que foram construídas dentro do tempo, mas custaram mais do que o contratado.

Porcentagem de obras que tenham aditivo só de tempo

Porcentagem de obras que conseguiram cumprir o orçamento, porém não conseguiram cumprir o cronograma, ou seja, custaram o planejado, mas foram construídas em um tempo maior que o estimado. 
Porcentagem de obras com ambos os aditivos

Porcentagem de obras que não cumpriram o orçamento nem o cronograma. São obras que atrasaram para finalizar e ainda tiveram valor mais alto do que contratado.

Porcentagem de aumento médio de aditivo de serviço

O valor da variação média do custo das obras. É esse índice que mostra quantos por centos uma obra ficou mais cara. De acordo com a LF 8.666/93, e citado no Capítulo 1, esse valor não pode exceder $25 \%$, no caso das nossas obras analisadas.

Porcentagem de aumento médio de aditivo de tempo

O valor da variação média do tempo de construção das obras. A LF 8.666/93 não prevê limite de tempo de construção de uma obra.

De posse desses cálculos, pode-se partir para as relações entre alguns dados. Esta pesquisa considera interessante comparar os seguintes:

Valor Estimado (VE) x Valor Contratado (VC)

Espera-se que o VE e o VC relacionem-se de forma direta, quanto maior um, maior o outro também e também que o VC seja menor que o VE.

Valor Estimado $x$ Valor Real (VR) (contratado + aditivo)

Subtraindo o VE do VR tem se a diferença entre o que a prefeitura calculou que custaria e o quanto realmente custou.

Valor Contratado x Valor Real

Esse mostra a porcentagem de quanto a obra custo diferente do que foi orçado. A diferença entre eles é a soma dos aditivos de serviço.

Valor Contratado $\mathrm{x}$ Valor aditivo (VA)

A relação entre eles é a porcentagem de aumento da obra. 
Tempo estimado (TE) $x$ tempo real (TR)

Como tempo de construção não é um parâmetro utilizado como decisivo nas licitações, a duração da obra e, por consequência, a vigência do contrato, são iguais ao tempo previsto pelo órgão público. O confronto desses dois dados mostra a porcentagem de aditivo de tempo existente na obra.

Porcentagem de aditivo de serviço $\times n^{\circ}$ pranchas

Com esta comparação analisa-se se existe relação entre o número de pranchas desenvolvidas para a obra e a porcentagem de aditivo de tempo. De acordo com Philippsen Junior e Fabrício (2011) e as respostas dos questionários desta pesquisa, espera-se que, com quanto maior o número de pranchas de projeto, menor seja a quantidade de aditivos de tempo das obras, ou seja, elas possuam um comportamento inversamente proporcional.

Porcentagem de aditivo de tempo $\times \mathrm{n}^{\circ}$ de pranchas

Este comportamento também é esperado para a relação do número de pranchas com os aditivos de serviço.

Porcentagem de aditivo de tempo $\mathrm{x}$ Porcentagem de aditivo de serviço

Essa relação é para confirmar se a relação dos dois tipos de aditivos é direta ou inversamente proporcional.

Após essas análises, foram feitas análises estatísticas realizadas em parceria junto a Empresa Junior de Estatística da Universidade Federal de São Carlos.

A fim de se atingir o objetivo, o banco de dados foi submetido inicialmente a uma análise descritiva e, em seguida, a uma análise de correlação, realizadas com o auxílio dos softwares Microsoft Excel. 


\subsubsection{ANALISAR OS DADOS}

A análise descritiva ou exploratória proporciona uma visão do comportamento geral do banco de dados em relação ao objetivo principal do estudo. Permite também avaliar se existem empecilhos na realização de análises posteriores, dando margem ao pesquisador para realizar mudanças pertinentes, evitando conclusões errôneas. Para tanto, foram construídas tabelas de frequências, devido à natureza categórica dos dados.

\subsubsection{Coeficiente de Correlação de Spearman $(\boldsymbol{\rho})$}

Este cálculo foi realizado pela empresa júnior. Ele foi utilizado na tentativa de identificar relação entre alguns fatores, mostrados mais a frente.

O coeficiente de correlação de Spearman $(\rho)$ mede a intensidade da relação entre variáveis ordinais. Usa, em vez do valor observado, apenas a ordem das observações. É dado por:

$$
\rho=1-\frac{6 \sum_{i=1}^{n} d_{i}^{2}}{n^{3}-n}
$$

Onde:

$d_{i}^{2}$ é a diferença entre cada posto de valor correspondentes entre as variáveis, e n= número dos pares dos valores.

Nos casos em que os dados não estão homogeneamente dispostos, com alguns pontos bem distantes dos demais, ou em que parece existir uma relação crescente ou decrescente num formato de curva, o coeficiente de correlação de Spearman é mais apropriado. Ele também pode ser usado quando os dados não pertencem a uma escala de medida padrão.A medida varia de -1 a 1 sendo que quanto mais perto dos extremos maior é a correlação entre as variáveis, quanto mais próximo de -1 a correlação é negativa e quanto mais próximo de 1 a correlação é positiva. 


\section{Análise e interpretação dos dados}

Este capítulo é destinado à análise e interpretação dos dados levantados. Serão mostrados os gráficos e tabelas obtidos e a discussão desses números.

Seguindo o roteiro proposto o primeiro dado a ser analisado é quantidade de obras que se encontravam sob processo judicial e, por consequência, parados. Dos 34 (trinta e quatro) processos que se encaixavam nos critérios estabelecidos, 9 (nove) estavam parados esperando uma decisão da justiça. Ou seja, esse primeiro dado mostra que $26,50 \%$ licitações abertas acabaram em processos judiciais, causando perdas para ambas as partes, principalmente para a população, que deixa de constar com um equipamento público. Esse alto índice já mostra problemas de gerenciamento das obras públicas.

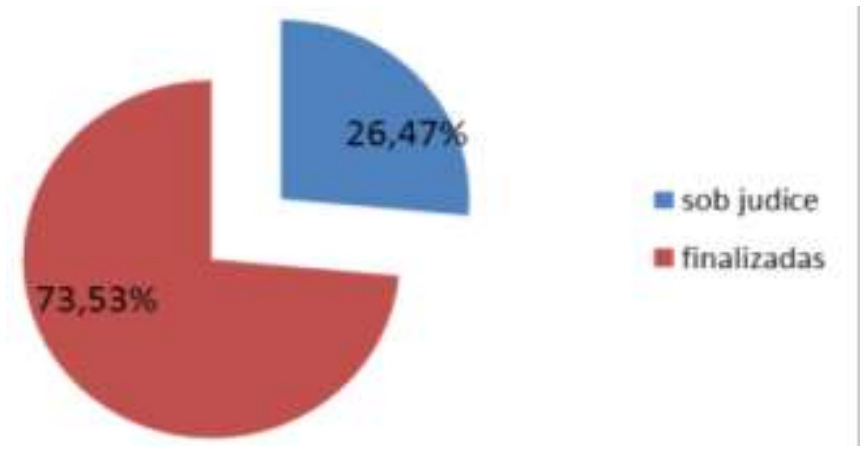

Gráfico 4-1. Porcentagem de obras em processo judicial

Analisando os processos dessas 9 (nove) obras relacionado aos projetos elaborados para as obras, obteve-se a tabela mostrada a seguir: 


\begin{tabular}{ccc} 
Código da obra & $\begin{array}{c}\text { Variedade de projetos } \\
\text { (unidades) }\end{array}$ & $\begin{array}{c}\text { Número de pranchas } \\
\text { (unidades) }\end{array}$ \\
\hline SA.AM.BS.LOP.09 & 4 & 27 \\
ED.AM.IN.OCT.09 & 1 & 1 \\
ED.AM.BA.GAL.09 & 1 & 2 \\
ED.AM.IN.TOB.09 & 1 & 1 \\
ED.CO.IN.BEN.09 & 2 & 2 \\
ED.CO.IN.COT.10 & 6 & 13 \\
ED.CO.IN.PER.09 & 13 & 64 \\
ED.CO.IN.NOV.10 & 12 & 73 \\
ED.CO.IN.DOM.09 & 12 & 73 \\
\hline
\end{tabular}

Tabela 4-1. Tabela de obras sob judice

Observa-se a média de quase 28,5 folhas de projetos para cada obra. A disparidade entre as obras ED.CO.IN.PER.09, ED.CO.IN.NOV.10 e ED.CO.IN.DOM.09 e as demais é devido ao fato de que, como tais obras são referentes a construção de novas escolas, o Ministério da Educação e Cultura, MEC, oferece três modelos de projeto padrão para arquitetura executivo, fundações, instalações hidrossanitárias, instalação de esgoto, instalação elétrica e telefonia, estrutura metálica, instalação de água fria, drenagem de água pluviais, prevenção de combate à incêndio, ar condicionado, sistema de proteção de descargas atmosféricas, instalação de gás e ventilação mecânica. Cabe à prefeitura contemplada com o financiamento a elaboração de projeto arquitetônico para implantar o projeto no terreno escolhido. Prática de projeto que não garante qualidade.

Infelizmente, a justificativas para os aditivos não constavam dos processos. Assim, não se pode tecer conclusões sobre as suas causas. Porém, a partir de conversas com os funcionários da secretaria de obras, e documentadas pelos questionários, constatou-se que os funcionários atribuem a falhas de projeto como a causa de tantos problemas encontrados nas obras. O parâmetro utilizado para 
mensurar os projetos foi quantidade de pranchas e especialidade de projetos desenvolvidos.

Mesmo a lei das licitações sendo uma lei antiga necessitando de atualização, a sua descrição de projeto básico difere-se, e muito, dos encontrados nessa pesquisa. Foram encontrados poucos projetos desenvolvidos exclusivamente para a obra em questão. Em obras financiadas pelo MEC, é enviado para a prefeitura municipal, um jogo de projetos completo, contendo, em média, 74 pranchas divididas em 12 especialidades de projeto. Cabendo à prefeitura municipal desenvolver um projeto de implantação da edificação no terreno escolhido. Quatro obras seguiram esse projeto do MEC para sua execução, três delas com orçamento estimado próximo a $R \$ 1,2$ milhões. Apesar de 2 obras que receberam esses projetos apresentarem números animadores, com porcentagens baixas de aditivos, como mostra a tabela 5.2 , as outras duas obras estão com pendencias judicias, paradas, esperando a resolução do problema. Com dados assim, não é possível afirmar que esse tipo de projeto seja a solução.

Para continuação das análises propostas foram utilizadas as outras 25 obras restantes. Além das porcentagens propostas pelo roteiro e outros cálculos como médias, desvio padrão, variância, $1^{\circ}, 2^{\circ}$ e $3^{\circ}$ quartis foram calculados pela Empresa Júnior de Estatística (EJE) da Universidade Federal de São Carlos. Assim, os dados que seguem são extraídos do relatório elaborado pela EJE, transcrito na íntegra ao final desta dissertação, no anexo X.

Como se vê no

Gráfico 4-2 que somente 4\% das obras estudadas não apresentaram aditivos em sua execução, ou seja, foi possível concluir a construção do equipamento público dentro do preço e do tempo estipulados pelo contrato. O restante dos $96 \%$ das obras possuíam alguma modalidade de aditivo, seja de serviço ou de tempo ou ambos. 
Mesmo ciente de que as obras estudadas nas referencias bibliográficas são de natureza diferente das estudadas nessa pesquisa, comparando-as entre si pode-se perceber que as médias obtidas neste estudo são ainda maiores. Quando comparadas

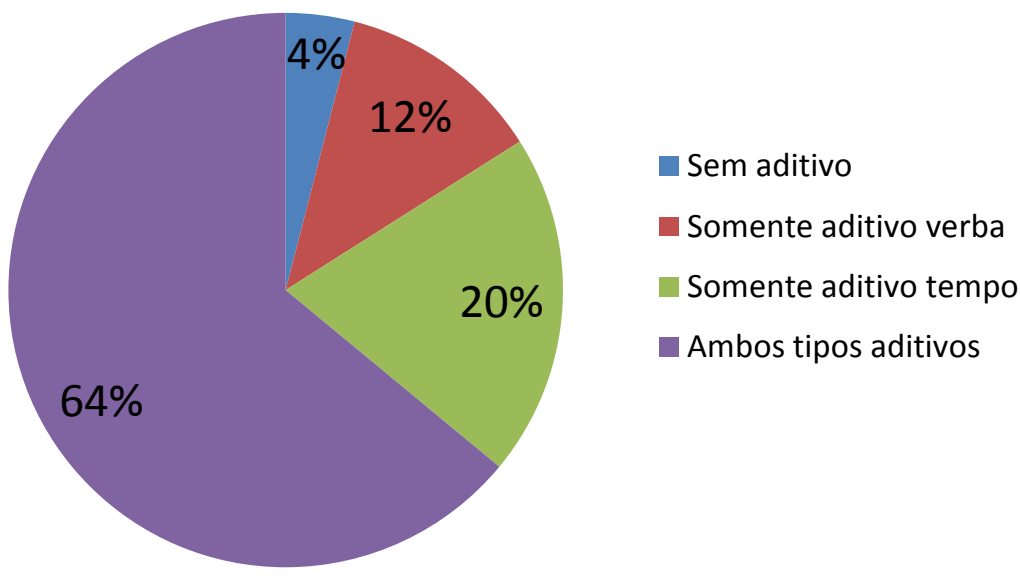

Gráfico 4-2. Porcentagem de obras com aditivos

a quantidade de obras que utilizam os aditivos de tempo, o estudo mostrou-se somente ligeiramente maior do que o apresentado pela literatura, mas também muito próximo da totalidade das obras, $84 \%$ no caso.

\begin{tabular}{cccc}
\hline Autor & $\begin{array}{c}\text { País } \\
\text { estudado }\end{array}$ & $\begin{array}{c}\text { Obras com } \\
\text { atrasam }\end{array}$ & $\begin{array}{c}\text { Média de aumento } \\
\text { de tempo }\end{array}$ \\
\hline Khalil, Gahfly (1999) & $\begin{array}{c}\text { Arábia } \\
\text { Saudita }\end{array}$ & $70 \%$ & $110 \%$ \\
Elinwa, Josue (2001) & Nigéria & $80 \%$ a $90 \%$ & $89 \%$ \\
Dados analisados & Brasil & $84 \%$ & $201,20 \%$ \\
\hline
\end{tabular}

Tabela 4-2. Porcentagens de aditivos de tempo

Apesar da natureza das obras analisadas na literatura ser diferente das obras estudadas, pois apresentam maior complexidade de execução, ao analisar a média de aumento do tempo, nota-se que a porcentagem encontrada nos estudos desta 
pesquisa está muito acima dos dados da bibliografia, sendo, quase, o dobro das outras médias encontradas. Isso agrava mais o índice anterior, pois mostra que a probabilidade de que qualquer obra executada por essa prefeitura municipal atrasar é de $84 \%$ e essa obra deve demorar mais do que duas vezes do que o previsto.

No GRÁfICO 4-3 faz-se a análise dos valores referentes ao tempo dos contratos. Mesmo o cronograma sendo um dos documentos exigidos na licitação, o tempo de obra não é um parâmetro decisivo no processo de licitação, diferente do que ocorre com as análises referentes a serviço, tem-se somente três valores para análise: (1) o tempo estimado pela prefeitura para a execução da obra, (2) a soma dos valores de aditivos de tempo solicitados para que a obra pudesse ser concluída e (3) o tempo total que a obra levou para ser concluída. Ou seja, o tempo estimado da obra somado aos aditivos de tempo resulta no tempo total da obra, representado pela expressão a seguir:

T.E. + Ad. T. $=$ T.R.

Onde:

T.E. = tempo estimado

Ad. T. $=$ aditivo de tempo

T.R. = tempo real de obra

Com o GRÁfICo 4-3 é possível fazer mais análises do que somente a comparação com os índices encontrados nos artigos. Este Erro! Fonte de referência não encontrada. compara o tempo estimado pela prefeitura municipal para a execução da obra com o tempo que a obra realmente levou para ser finalizada de todas as obras analisadas. No eixo $X$ do gráfico, temos listadas as obras analisadas com os nomes codificados. No eixo Y está representada a porcentagem de aumento de tempo necessário para a finalização da obra. A barra bege representa os aditivos de contrato. 
Cada segmento representa um novo termo aditivo assinado entre a prefeitura e a empresa contratada, e seu tamanho é proporcional ao tempo solicitado. Assim, é possível ver também a quantidade de aditivos. A linha verde mostra o valor médio dos aditivos de contratos referentes ao tempo.

Essa alta média de aditivos é impulsionada também por três obras que tiveram grandes aumentos de tempo, pois a mediana é $150 \%$, de acordo com os cálculos estatísticos. Porém, elas não são as únicas culpadas desse alto valor. Analisando ainda o Erro! Fonte de referência não encontrada., percebe-se que existem outras cinco obras que estão próximas aos $400 \%$ de tempo de obra, índice muito ainda muito alto. Essas análises mostram também que $75 \%$ das obras atrasam $275 \%$, valor maior ainda do que a média ou a mediana. Pode-se perceber que a situação dos aditivos de tempo é bastante crítica, pois seus números são altos.

Comparando a média de aditivo de tempo encontrada na pesquisa com os dados levantados na literatura, o valor encontrado é maior que o dobro. A LF 8.666/93 não estabelece um limite para a construção da obra, o que possibilita tantos aditivos assim.

Outro dado que pode ser extraído deste GRÁFIco 4-3Erro! Fonte de referência não encontrada. é a quantidade de aditivos utilizados em cada obra. Nota-se o predomínio de grande quantidade de aditivos com a duração de tempo mais curta do que o necessário, fazendo necessária essa grande quantidade. Isso mostra falta de planejamento global da obra. Mesmo após a assinatura do contato, quando o controle da obra está sob responsabilidade da construtora, o cronograma estipulado para o término da obra não é cumprido, então faz-se necessário novos aditivos. Na análise dos processos foram encontrados somente cronogramas ligados ao processo licitatório, ou seja, o cronograma temporal e o de desembolso físico-financeiro, que atrela o custo de cada etapa a sua construção. Porém, para a assinatura dos novos 
aditivos não foi encontrado novo cronograma proposto, salvo raras exceções que tiveram como justificativas causas meteorológicas. 


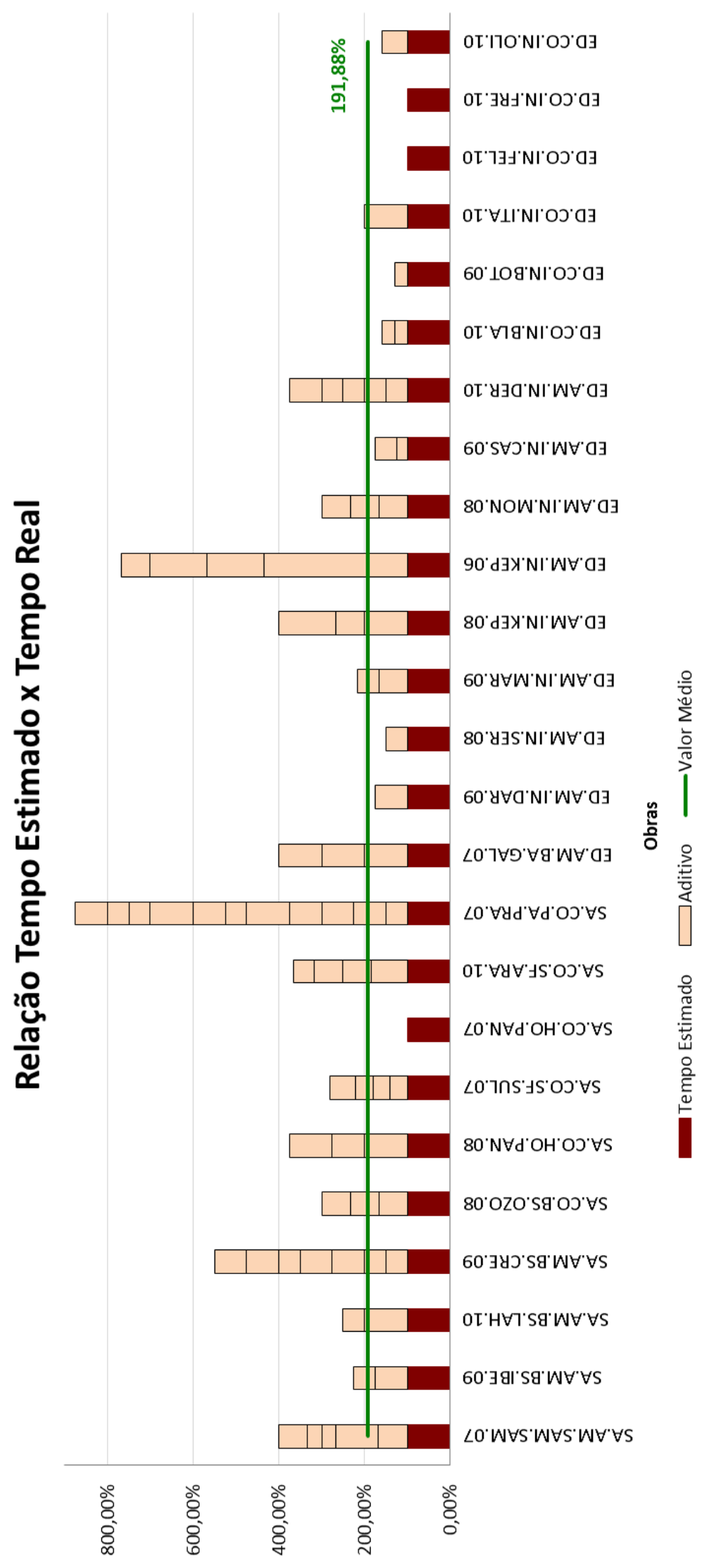

Gráfico 4-3. Relação tempo estimado x tempo real 
Outra dificuldade encontrada nessa pesquisa está relacionada às causas dos aditivos, tanto de serviço quanto de tempo, raramente eram esclarecidas nos processos, de modo que, as mostradas não seriam expressivas para confrontar os dados com a literatura pesquisada.

Identifica-se no GRÁFICO 4-3 duas obras com valores de aditivos de tempo muito acima da média, o SA.CO.PA.PRA.07 e o ED.AM.IN.KEP.06. Estas duas obras tiveram o valor do aditivo de contrato tão altos porque foram obras que passaram por ações judiciais, assim tiveram a entrega da obra adiada demasiadamente.

No quesito de aditivos de serviços tem-se a seguinte situação levantada na literatura estudada:

\begin{tabular}{cccc}
\hline Autor & $\begin{array}{c}\text { País } \\
\text { estudado }\end{array}$ & $\begin{array}{c}\text { Obras com } \\
\text { aditivo de } \\
\text { serviço }\end{array}$ & $\begin{array}{c}\text { Média de } \\
\text { aumento } \\
\text { custo }\end{array}$ \\
\hline $\begin{array}{c}\text { Flyvberj, Holm, Buhl } \\
(2007)\end{array}$ & Noruega & $85 \%$ & $28 \%$ \\
Dados analisados & Brasil & $80 \%$ & $13,67 \%$ \\
\hline Tabela 4-3. Tabela comparativa de aditivo de serviço & & \\
\hline
\end{tabular}

Como o parâmetro para definir o vencedor de um processo de licitação é o valor da obra, para esta análise conta-se com 4 (quatro) valores significativos: (1) o custo estimado pela prefeitura para a execução da obra, (2) o valor vencedor da licitação e objeto no contrato assinado entre as partes, (3) a soma dos valores de aditivos de serviço solicitados para que a obra pudesse ser concluída e (4) o custo real total que a obra teve para ser concluída. Assim, o valor contratado somado aos aditivos de serviço gera o custo real da obra, representado pela expressão a seguir:

$$
\text { C.E. + Ad. S. = C.R. }
$$

Onde:

C.E. $=$ custo estimado

Ad. S. = aditivo de serviço

C.R. = custo real de obra 


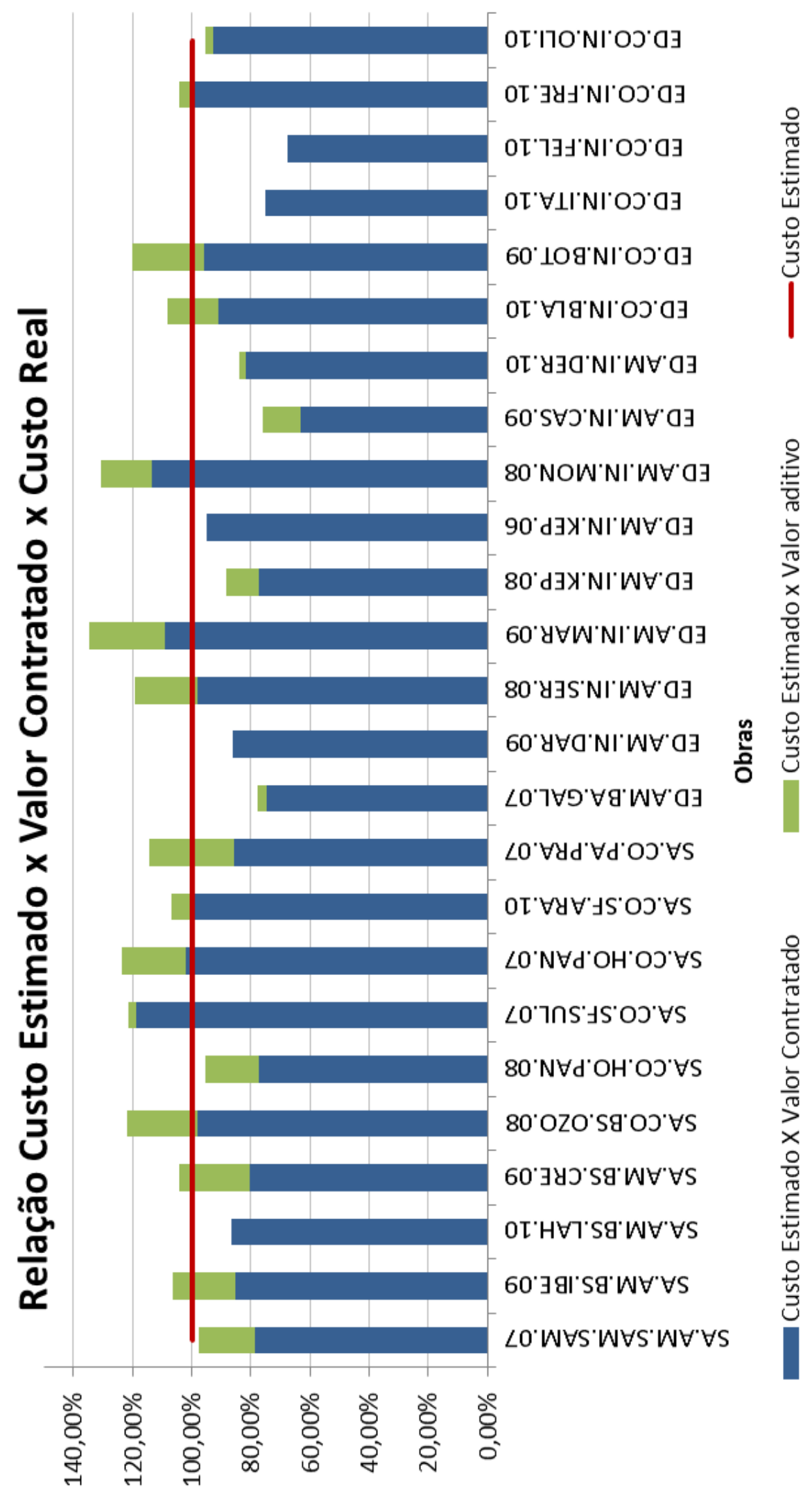

Gráfico 4-4. Relação custo estimado $x$ valor contratado $x$ custo real 
Os eixos do gráfico são compostos pela listagem das obras no eixo $\mathrm{X}$ e pela porcentagem em relação ao custo estimado da obra. A linha vermelha representa o custo estimado da obra, que, obviamente, cruza o eixo Y no valor $100 \%$. A barra azul mostra a porcentagem que o valor contratado representa do valor estimado. A barra verde posicionada acima da barra azul, quando existente, representa o total de aditivo de serviço utilizado em determinada obra. A soma da barra azul com a parcela verde é o custo real da obra.

No GRÁFICO 4-4, comparando, inicialmente, o custo estimado com o valor contratado é possível ver que 4 obras tiveram o valor contratado superior ao valor estimado ${ }^{1}$, e essas obras ainda contaram com aditivos, em média de 16,66\%, valor até maior do que a média de aumento de todas as obras desta prefeitura.

Analisar a relação entre valor contratado e custo real é analisar a presença de aditivos. Assim, as obras que tiveram termos aditivos de serviço possuem a barra verde como complemento. Neste gráfico pode-se confirmar o dado mostrado na tabela que mostra que somente cinco obras em vinte e cinco estudadas não tiveram aditivos de serviço. Isso quer dizer que $80 \%$ das obras custaram mais do que o contratado assinado. Porém, comparando o custo real com o valor estimado, tem-se que $52 \%$ das obras tiveram seu preço final maior do que o esperado inicialmente.

O GRÁFICO 4-5 compara os seguintes dados: (1) o valor vencedor da licitação, ou seja, o valor pelo qual foi assinado o contrato de execução da obra, (2) e o valor total, calculado pela soma do valor do contrato inicial e todos os aditivos. Ou seja, o valor

${ }^{1}$ Esta prática é permitida desde que haja um parecer dos profissionais competentes dos órgãos públicos alegando que os valores unitários propostos pelo vencedor são condizentes com as praticadas no mercado. 


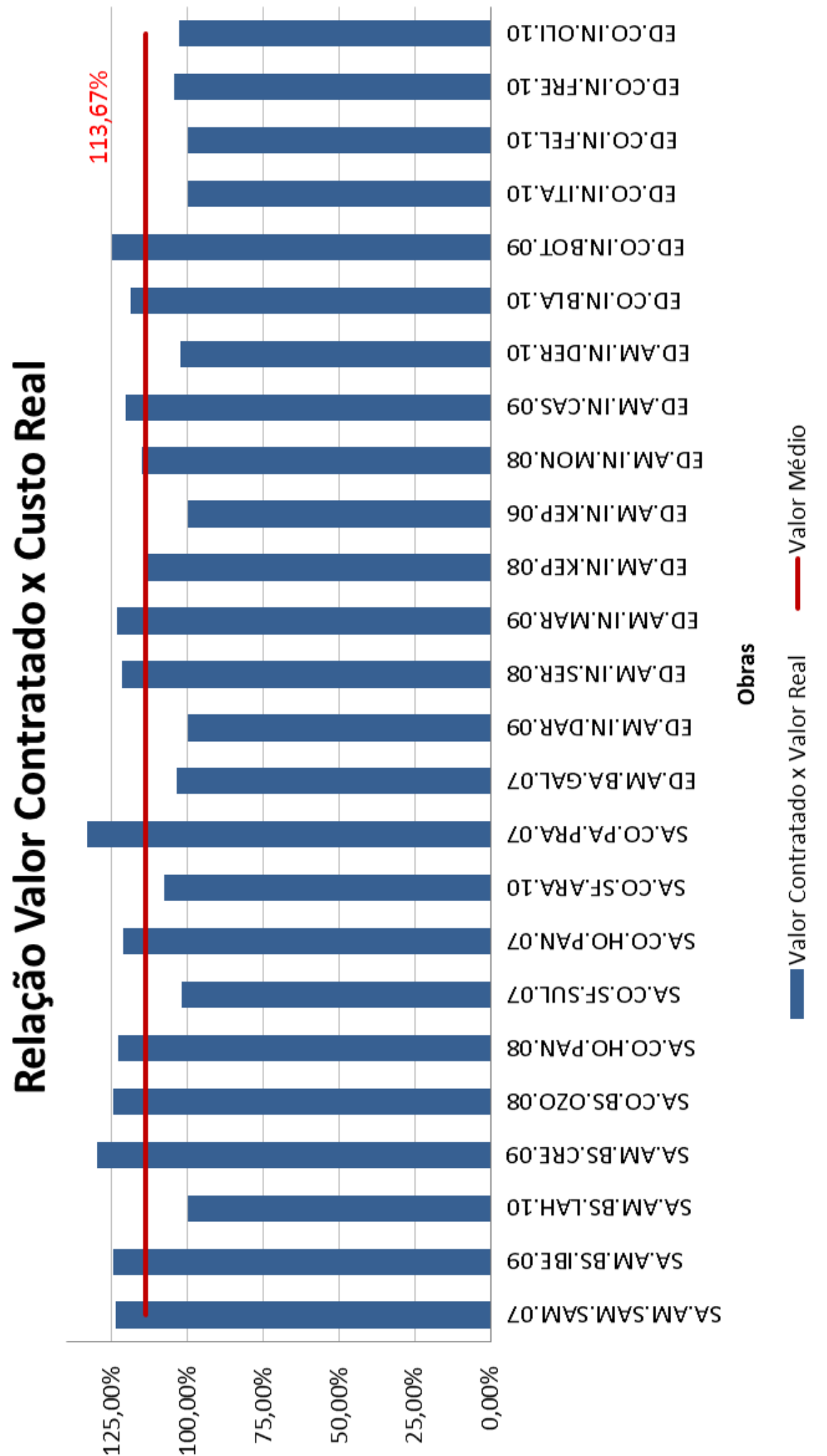

Gráfico 4-5. Relação entre valor contratado e custo real 
contratado somado aos aditivos de serviços resulta no quanto a obra realmente custou. A expressão a seguir representa essa relação:

V.C. + Ad. S. $=$ C.R.

Onde:

V.C. $=$ valor contratado

Ad. S. = aditivo de serviço

C.R. = custo real

No eixo $X$ do GRÁfICo 4-5, são listadas as obras analisadas codificadas. No eixo $Y$ está representada a porcentagem de aumento de custo da obra. A barra azul representa o porcentual da relação entre o valor contratado e o valor real pago pela construção do equipamento. A linha vermelha mostra o valor médio, em porcentagem do custo real em relação ao valor contratado.

Verifica-se a existência de 11 obras possuindo valores de aditivos próximos aos $25 \%$ permitidos pela LF $8.666 / 93$, com médias de aditivo de $24,60 \%$. Isso mostra que $55 \%$ das obras solicitam quase que a totalidade de aditivos de serviços permitidos por lei. Porém, a média de aditivos é 13,67\%, como mostrado no GRáFICo 4-5. Considerando que ainda tiveram 5 obras sem aditivos de serviço, pode-se dizer que a média não retrata a realidade, pois a grande parte desses aditivos encontram-se nas extremidades dessa média. Assim, as ações para a solução desses problemas devem ter foco prioritário em obras que possuem aditivos em torno de $25 \%$.

No GRÁfICO 4-6 compara-se os seguintes dados: (1) o custo estimado, ou seja, o valor da planilha orçamentária calculada pelos funcionários públicos para a licitação, (2) e o valor contratado, o vencedor da licitação. 


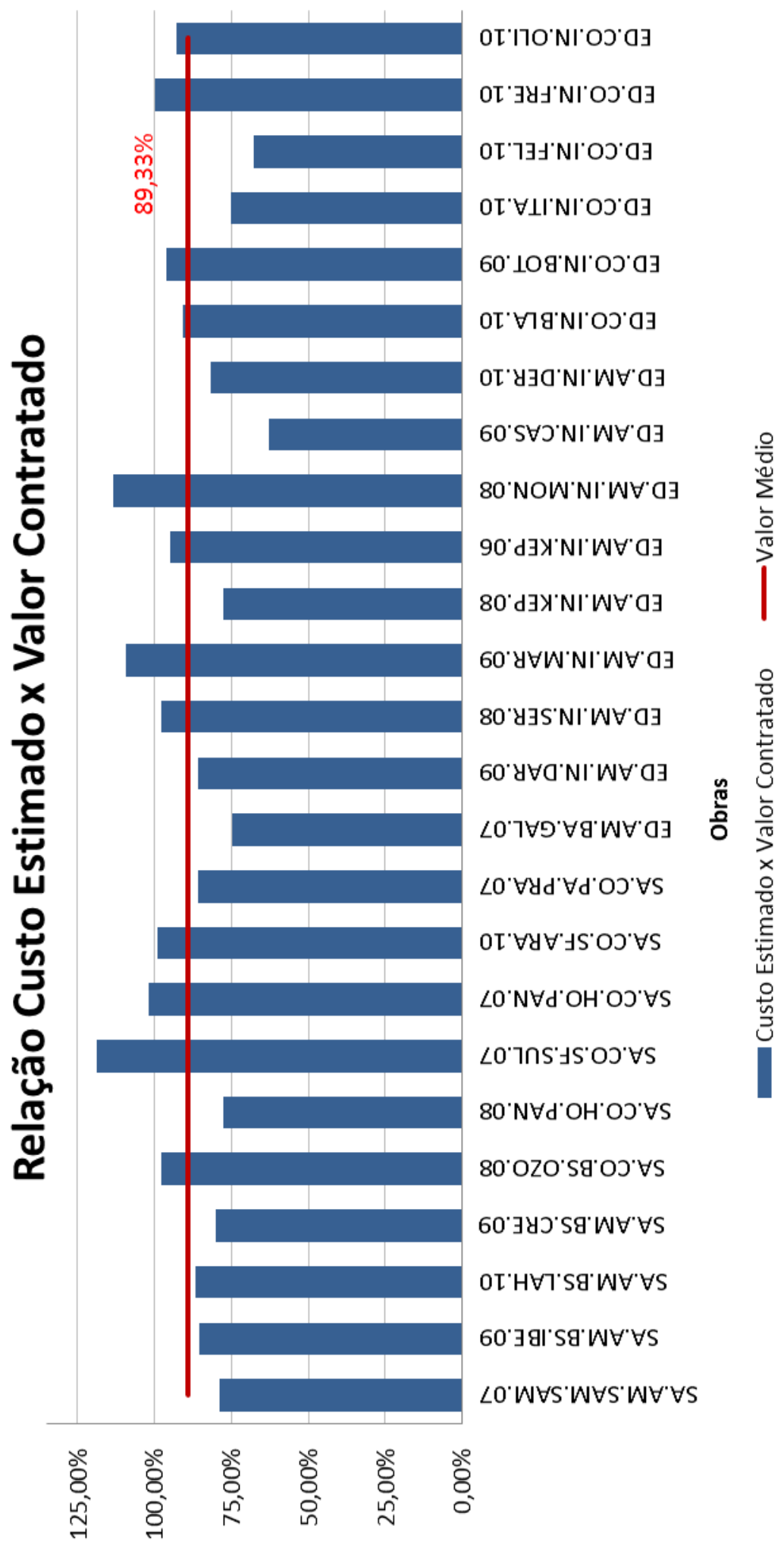

Gráfico 4-6. Relação entre o valor estimado e o valor contratado 
No eixo $\mathrm{X}$ do gráfico, estão listadas as obras analisadas com os nomes codificados. No eixo Y está representada a porcentagem de aumento de custo da obra. A barra azul representa o valor do contrato em relação ao custo estimado. A linha vermelha mostra a média de quanto os vencedores da licitação representam do valor estimado.

Em média, os vencedores das licitações apresentam o preço em torno de $90 \%$ do valor estimado pelo órgão público.

No eixo $X$ do gráfico 5.5 , estão listadas as obras analisadas com os nomes codificados. No eixo Y está representada a porcentagem de aumento de custo da obra. Nota-se que o gráfico de aditivos de serviço não repete o comportamento dos aditivos de tempo, na qual são encontrados muitos aditivos com valor baixo. Aqui observa-se a presença de poucos aditivos, mas com o valor próximo ao total solicitado. Quando há a utilização de mais aditivos, eles aparentam ser somente uma complementação necessária para chegar ao ajuste da obra. Os valores negativos presentes nesse gráfico indicam que nas medições realizadas foi concluído que as construtoras deveriam devolver dinheiro ao órgão público devido à alguma alteração que possa ter ocorrido. 


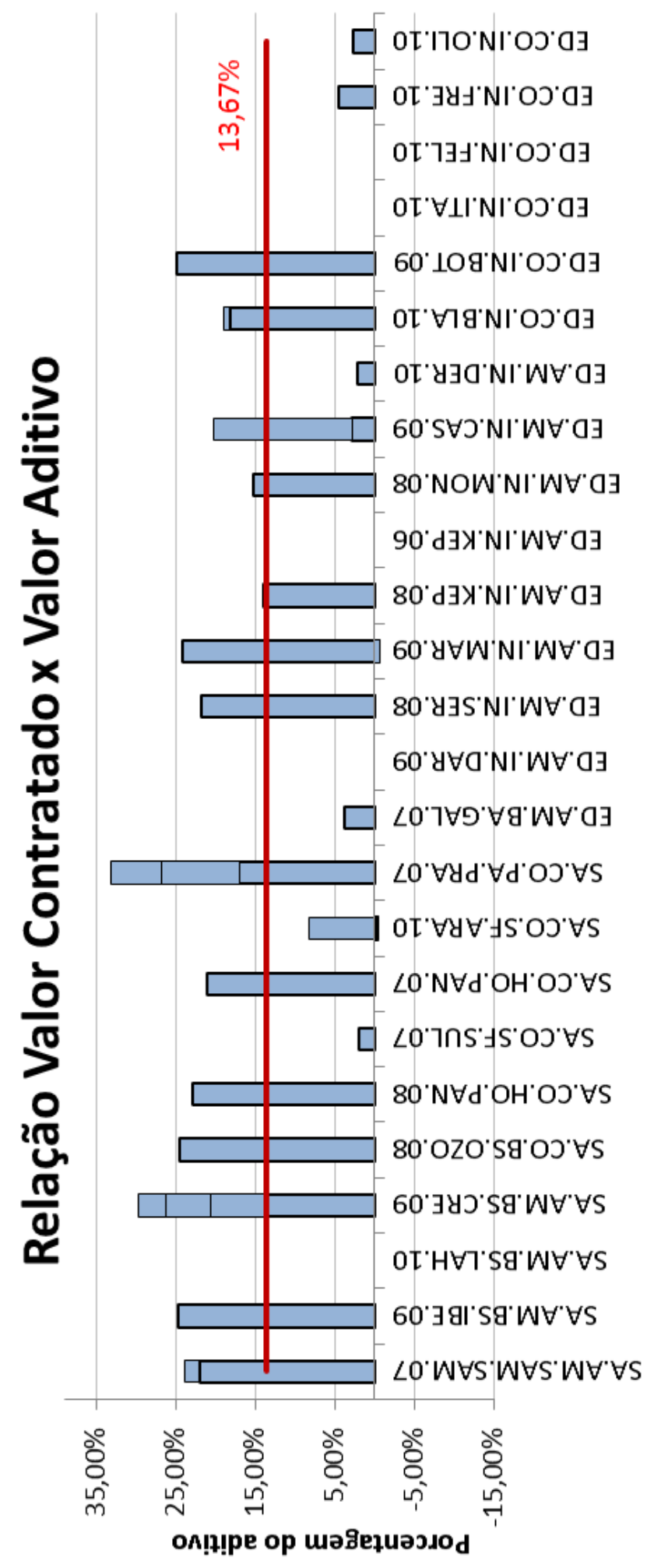


Os dados comparados estão mostrados na TABELA 4-4, já com os valores dos seus coeficientes de Spearman calculados. Desta análise, tem-se o seguinte quadro de comparações:

Variáveis

Valor Estimado x Valor Contratado

Valor Estimado x Valor Real

Valor Contratado x Valor Real

Valor Contratado x Valor aditivo

Tempo Estimado x Tempo Real

$\%$ de Aditivo de Tempo $\times \mathrm{N}^{\circ}$ Pranchas

$\%$ de Aditivo de Serviço $\times N^{\circ}$ Pranchas

$\%$ de Aditivo de Tempo x \% de Aditivo

de Serviço

$\mathrm{N}^{\circ}$ de Variedades de Projetos $\times \mathrm{N}^{\circ}$ de

Pranchas
Coef. de Correlação

0.98

0.9523077

0.9653846

0.5930546

0.625591

$-0.08539915$

0.1155935

0.1598299

$-0.05222956$

Pode-se notar que há correlações fortes e positivas nas três primeiras situações, ou seja, quanto maior o valor estimado da obra, maior será o valor real e o contratado. Em relação ao tempo, a correlação é positiva e moderada entre o tempo estimado e o tempo real da obra, o que pode indicar que os tempos são proporcionais. As outras correlações são consideradas fracas, pois são inferiores a 0.3 , embora seja negativa para \% de aditivo de tempo e número de pranchas, e número de variedades de projetos e número de pranchas. 


\section{CONCLUSÃO}

Esta pesquisa teve como objetivo estudar e analisar as ocorrências de aditivos de tempo e de serviço em contratos de obras públicas. Para isso, foram estudadas obras para construção de equipamentos públicos de educação e saúde em um município brasileiro.

A pergunta a ser respondida foi: por que obras públicas, geralmente, necessitam de aditivos de contrato? Porém, ela não possui uma única resposta, pois os motivos que geram esse aumento de prazo ou de custo de uma obra são variados.

Antes da resposta, é interessante ressaltar alguns pontos detectados na pesquisa. Nota-se que a porcentagem de obras que possuem aditivos de contrato é alta, porém é próxima aos dados mundiais. O que difere são as causas geradas dessa complementação.

A mais grave situação é a relacionada ao tempo de construção. Os aditivos que aumentam a duração da obra são mais frequentes e de valores maiores se comparados aos que modificam o preço. Isso talvez ocorra devido á algumas leis. A LF 8.666/93 que estabelece um limite para os aditivos de serviços e a pela LF101/2000, a lei de responsabilidade fiscal, na qual o prefeito não pode deixar dívidas pendentes para a próxima gestão, sob pena de prisão, por improbidade administrativa.

A principal causa, para o caso estudado, de acordo com os questionários respondidos pelos engenheiros responsáveis pela fiscalização das obras é a falta de projetos executivos bem elaborados, que apresentem qualidade arquitetônica e construtiva.

Apesar de existir uma porcentagem significativa de aumento de preço final em relação ao custo estimado nas obras analisadas, a pior situação é em relação aos aditivos de tempo. Os índices encontrados são muito superiores às medias internacionais encontradas na bibliografia. Uma das causas dos índices tão altos de 
aditivos de tempo é o fato da LF 8.666/93 não estabelecer limite como máximo de tempo passível de aditamento, o que precisa ser revista.

Recomenda-se também, como descrito nas referencias maior atenção às etapas de planejamento da obra. Projetos completos, bem elaborados são primordiais para um bom andamento das obras. Assim, prever, em papel, os problemas que poderiam acontecer, deixa a obra mais rápida e mais barata, pois as soluções já foram encontradas em projetos.

Necessita-se também desenvolver nos gestores púbicos o pensamento de que a parte de planejamento não é perda de tempo e de investimento. Muito pelo contrário, investir nesse ponto é evitar gastos desnecessários e conseguir cumprir o prazo de construção.

Conclui-se também que este trabalho contribuiu para os estudos sobre gestão de obras públicas no Brasil. Como ainda há muito a ser pesquisado, esta pesquisa visou dar subsídios e incentivos para mais pesquisas sobre o tema. Acredita-se que os primeiros passos estão sendo dados em direção a dar mais qualidade às obras públicas e que pode as pesquisas em obras públicas possam chegar ao grau de abrangência e especificação das pesquisas para obras particulares.

Acredita-se, sobretudo, na importância social de pesquisas como esta. Os atrasos mostrados nessa pesquisa são referente à obras de Saúde e Educação, necessidades básicas que o Estado é obrigado a provir. Cada dia de atraso de obra representa um cidadão que teve um atendimento médico ruim em outro posto ou uma criança que teve aula em condições ruins em outra escola, caso tenham conseguido ter alguma forma de atendimento.

Propõe-se que as próximas pesquisas da área abranjam um numero maior de obras para análise. Obras de uma prefeitura não foram suficientes para criar um diagnóstico da situação geral. 
Crê-se também que é necessário abranger uma variedade maior de assuntos. 0 processo licitatório é de alta importância de ser estudado. A fiscalização e seus procedimentos de medição também são pontos que merecem maiores atenção e dedicação.

A falta de informações nos processos, principalmente referente às justificativas dos aditivos foi um quadro que prejudicou bastante a pesquisa, pois são informações que seriam de suma relevância nos estudos. Esse quadro de omissão prejudica o desenvolvimento de pesquisas.

Em um país em desenvolvimento, com grandes obras públicas acontecendo neste momento histórico, com bilhões de reais investidos, deixando o Brasil em papel de destaque no cenário internacional, não se pode deixar que as obras públicas continuem a acontecer sem um planejamento eficaz, assim, esta pesquisa buscou contribuir, mesmo que com um pequeno passo, para o desenvolvimento do país. 


\section{REFERÊNCIAS BIBLIOGRÁFICAS}

ABBASI, G.Y.; MHARMAH, H. (2000) Project management practice by the public sector in a developing country. International Journal of Project Management. V. 18 n. 02 p. 105-109

AL-KHARASHI, A.; SKITMORE, M. (2009) Causes of delays in Saudi Arabian public sectorconstruction projects. Construction Management and Economics. V. 27 p. 3-23

AHMED S. ET AL (2002) Construction delays in Florida; an empirical study, Florida; http://www.cm.fiu.edu/pdfs/Research Reports/Delays Project.pdf. visitado em 21.10.2012

ARDITI, D.; AKAN, G. T.; GURDAMAR, S. (1985) Cost overruns in public projects. International Journal of Project Management. v. 3, n. 4, p 218-224

BRASIL. Constituição (1988). Constituição da República Federativa do Brasil. Brasília, DF: Senado

BRASIL (1993) Lei $\mathbf{n}^{\circ} \mathbf{8 . 6 6 6}$, de 21 de julho de 1993. Regulamenta o art. 37, inciso XXI, da Constituição Federal, institui normas para licitações e contratos da Administração Pública e dá outras providências.

BRETAS, E.S. (2010) O processo de projetos de edificações em instituições públicas: proposta de um modelo simplificado de coordenação. 152 p. Dissertação (Mestrado) Universidade Federal de Minas Gerais, Escola de Engenharia: Belo Horizonte.

CRETELLA JÚNIOR, J. (2006) das licitações públicas. Comentários à Lei Federal $n^{\circ}$ 8.666, de 21 de junho de 1993, republicada no Diário Oficial de 6 de julho de 1994, conforme determinação do art. $3^{\circ}$ da Lei $n^{\circ} 8.883$, de 8 de junho de 1994; redação posteriormente alterada pelas Leis $n^{\text {os }} 8.987$, de 13.02.1995; 9.7]074, de 07.07.1995; 9.472, de 16.07.1997; e 9.648, de 27.05.1998.) Rio de Janeiro: Editora Forense, 18a Ed. $619 p$.

DALLARI, P. (1994). Constituição e relações exteriores. Editora Saraiva.

DOLOI, H.; et al (2012), Analysing factors affecting delays in Indian construction projects. . International Journal of Project Management. V. 30 p. 47-489

ELINWA, A.U.; JOSHUA, M., (2001) Time overrun factors in Nigerian construction industry. Journal of Construction Engineering and Management v. 127, p. 419-425. 
FALLAHNEJAD, M.H.; (2013) Delay causes in Iran gas pipeline projects. International Journal of Project Management. V. 31 p. 136-146

FRIMPONG, Y.; OLUWOYE, J.; edairy. L.; ( 2002) Causes of delay and cost overruns in construction of groundwater projects in a developing countries: Ghana as a case Study. International Journal of Project Management. V. 21 p. 321-326

FLYVBJERG, B.; BRUZELIUS, N.; ROTHERGATTER, W.; (2003) Megaprojects and risk. An anatomy of ambition. Cambridge: Cambridge University Press

FLYVBJERG, B.; HOLM, M. S.; BUHL, S. (2007) Underestimating costs in public works projects. Error ou lie? Journal of the American Planning Association V. 68 n. 03 p. $279-295$

HSIEH, T.Y.; LU, S.T., TZENG, G.H. (2004) Fuzzy MCDM approach for planning and design tenders selection in public office buildings. International Journal of Project Management. V. 22 p.573-584

KHALIL, M. I. (2002), Selecting the appropriate project delivery method using AHP, International Journal of Project Management, V. 20 p. 469-474

KHALIL, M. I.; GHAFLY, M. A.; (1999) Delay in public utility projects in Saudi Arabia, International Journal of Project Management, V. 17 n. 02 p. 101-106

KOLLTVEIT, B.J.; GRONHAUG, K. (2004) The importance of the early phase: the case of construction and building projects, International Journal of Project Management, V. 22 p. 545-551.

LAI, Y.T.; WANG, W.C.; WANG H.H. (2008) AHP- and simulation-based budget determination procedure for public building construction projects, Automation in construction, V. 17 P. 623-632

LIN, C.C.; WANG, W.C.; YU, W.D. (2008) Improving AHP for construction with na adaptive AHP approach $\left(A^{3}\right)$. Automation in construction, v. 17, p. 180-187

MAGNUSSEN, O. M.; OLSSON, N.O.E. (2006). Comparative analysis of cost estimates of major public International Journal of Project Management, v. 24, n. 4, p. 281-288

MARREWIJK, A. V. et al, (2008) Managing public-private megaprojects: Paradoxes, complexity and Project design, International Journal of Project Management. V. 26 p. 591-600

MELLO, C.A.B. (1978) Da Licitação, São Paulo: Bushatsky. 
MEREWITZ, L. (1973). Cost overruns in public works. Institute of Urban \& Regional Development, University of California.

MILLER, R.; LESSARD, D. (2001) Understanding and managing risks in large engineering projects, International Journal of Project Management. V. 19 p. 437-443

ORANGI, A.; PALANEESWARAN, E.; WILSON, J. (2011) Exploring Delays in Victoria-Based Australian Pipeline Projects. Procedia Engineering, v. 14 p. 874-881

PALANEESWARAN, E., KUMARASWAMY, M.M. (2008) An integrated decision support system for dealing with time extension entitlements. Automation in construction.v. 17 n.4 p. $425-438$

PHILIPPSEN JUNIOR, L.A.; FABRICIO, M.M.; (2011) Avaliação da gestão e coordenação de projetos - aspecto qualidade - de obras públicas vinculadas à Lei $n .0$ 8.666/93. II Simpósio Brasileiro de Qualidade do Projeto no Ambiente Construído X Workshop Brasileiro de Gestão do Processo de Projeto na Construção de Edifícios. Anais: Rio de Janeiro.

PUTHAMONT, S.; CHAROENNGAM, C. (2007) Strategic project selection in public sector: Construction projects of the Ministry of Defence in Thailand. International Journal of Project Management. V. 25 p. 178-188

RAZEK, A.M., BASSIONI, H., MOBARAK, A. (2008). Causes of Delay in Building Construction Projects in Egypt. Journal of Construction Engineering and Management. v. 134 n.11 p. 831-841.

SAATY, T.L. (1990) How to make a decision: The analytic hierarchy process. European Journal of Operational Research. V. 48, n. 1,p. 9-26

SEYDEL, J.; OLSON, D. L. (2001) Multicriteria support for construction bidding. Mathematical and computer modeling. v. 34 p. 677-702

STUMPF, G; (2000) Schedule delay analysis. Cost Engineering Journal. V.42 n.7 p.32-43.

TANG, L.; SHEN, Q.; CHENG, E.W.L. (2010) A review of studies on Public-Private Partnership projects in the construction industry. International Journal of Project Management. v. 28 n.7 p. 683-694

YANG, J.B.; YANG, C.C.; KAO, C.K.;(2010) Evaluating schedule delay causes for private participating public construction works under the Build-Operate-Transfer model. International Journal of Project Management. V. 28 p. 569-579 2005.

YIN, R.K. Estudos de caso: Planejamento e método. Bookman: Porto Alegre, 
Procedimentos para Autorização para realização do estudo de caso

Para poder ter acesso à documentação necessária para a realização do estudo de caso junto à SMOP da PM, foi enviado um pedido de autorização para análise dos processos à secretaria em questão. Como procedimento padrão interno, foi encaminhado para a Secretaria Municipal de Administração e Gestão Pessoal, SMAG, o pedido de abertura de um processo administrativo, que tramitou sob o número de 30.874/2010. O processo foi encaminhado ao Departamento de Negócios Jurídicos, DNJ, para a liberação junto aos advogados da PMSC com um parecer do então Secretário Municipal de Obras Públicas dizendo ser também de interesse da própria secretaria a realização desses estudos. Houve o parecer positivo do DNJ, porém, confundido com estágio foi encaminhado à Secretaria Municipal de Administração e Gestão de Pessoas (SMAGP) para os devidos procedimentos. Após conversa com funcionários da SMAGP e o esclarecimento de que não se tratava de estágio nem de algum vínculo empregatício com a PM o processo retornou ao DNJ para a liberação propriamente dita. Assim, finalmente o processo retornou a SMOP, com a autorização para o início das pesquisas de campo. 


\section{ANEXO II}

Explicação dos campos de codificação do nome das obras

$1^{\circ}$ Campo - Tipo de edificação

ED Educação

SA Saúde

TABELA 0-1. POSSIBILIDADES PARA PRIMEIRO CAMPO DO CODIFICAÇÃO DAS OBRAS

$2^{\circ}$ campo - Tipo de obra
AM Ampliação de prédio existente
CO Construção nova

Tabela 0-2. Possibilidades para segundo campo da codificação das obras

$3^{\circ}$ Campo - Uso da Edificação

\begin{tabular}{|c|c|c|}
\hline \multirow{4}{*}{ 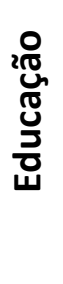 } & BA & Escola Municipal de Ensino Básico \\
\hline & IN & Escola Municipal de Ensino Infantil \\
\hline & JU & Centro da Juventude \\
\hline & BS & Unidade Básica de Saúde \\
\hline \multirow{4}{*}{$\frac{d}{\frac{0}{7}}$} & HO & Hospital \\
\hline & PA & Unidade de Pronto Atendimento \\
\hline & SA & Serviço de Atendimento Móvel de Urgência (SAMU) \\
\hline & SF & Unidade de Saúde da Família \\
\hline
\end{tabular}

Tabela 0-3. Possibilidades para terceiro campo da codificação das obras 


\section{ANEXO III}

Localização dos processos para levantamento de dados

Essa tabela mostra as repartições públicas nas quais se encontravam os referidos processos para o levantamento de dados.

\begin{tabular}{cccc}
\hline SA.AM.SAM.SAM.07 & SMOP & ED.AM.IN.KEP.08 & DPA \\
SA.AM.BS.IBE.09 & SMS & ED.AM.IN.KEP.06 & DPA \\
SA.AM.BS.LAH.10 & SMS & ED.AM.IN.MON.08 & SMOP \\
SA.AM.BS.LOP.09 & SMOP & ED.AM.IN.CAS.09 & PAT \\
SA.AM.BS.CRE.09 & SMOP & ED.AM.IN.DER.10 & EXP. \\
SA.AM.PA.FEL.10 & SMOP & ED.AM.JU.MON.07 & DPA \\
SA.CO.BS.OZO.08 & SMS & ED.AM.IN.TOB.09 & PAT \\
SA.CO.HO.PAN.08 & SMS & ED.CO.IN.BEN.09 & EXP. \\
SA.CO.SF.SUL.07 & SMS & ED.CO.IN.COT.10 & SMOP \\
SA.CO.HO.PAN.07 & SMS & ED.CO.IN.PER.09 & EXP. \\
SA.CO.SF.ARA.10 & SMS & ED.CO.IN.BLA.10 & EXP. \\
SA.CO.PA.PRA.07 & SMOP & ED.CO.IN.BOT.09 & SMOP \\
ED.AM.BA.GAL.07 & SMOP & ED.CO.IN.ITA.10 & DPA \\
ED.AM.IN.DAR.09 & DPA & ED.CO.IN.FEL.10 & DPA \\
ED.AM.IN.SER.08 & DPA & ED.CO.IN.FRE.10 & SMOP \\
ED.AM.IN.OCT.09 & PAT & ED.CO.IN.OLI.10 & EXP. \\
ED.AM.IN.MAR.09 & DPA & ED.CO.IN.NOV.10 & SMOP \\
ED.AM.BA.GAL.09 & SMOP & ED.CO.IN.DOM.09 & EXP. \\
\hline
\end{tabular}

TABELA 0-1. TABELA COM LOCALIZAÇÃO DOS PROCESSOS PARA ANÁLISE 
Formulário para levantamento de dados

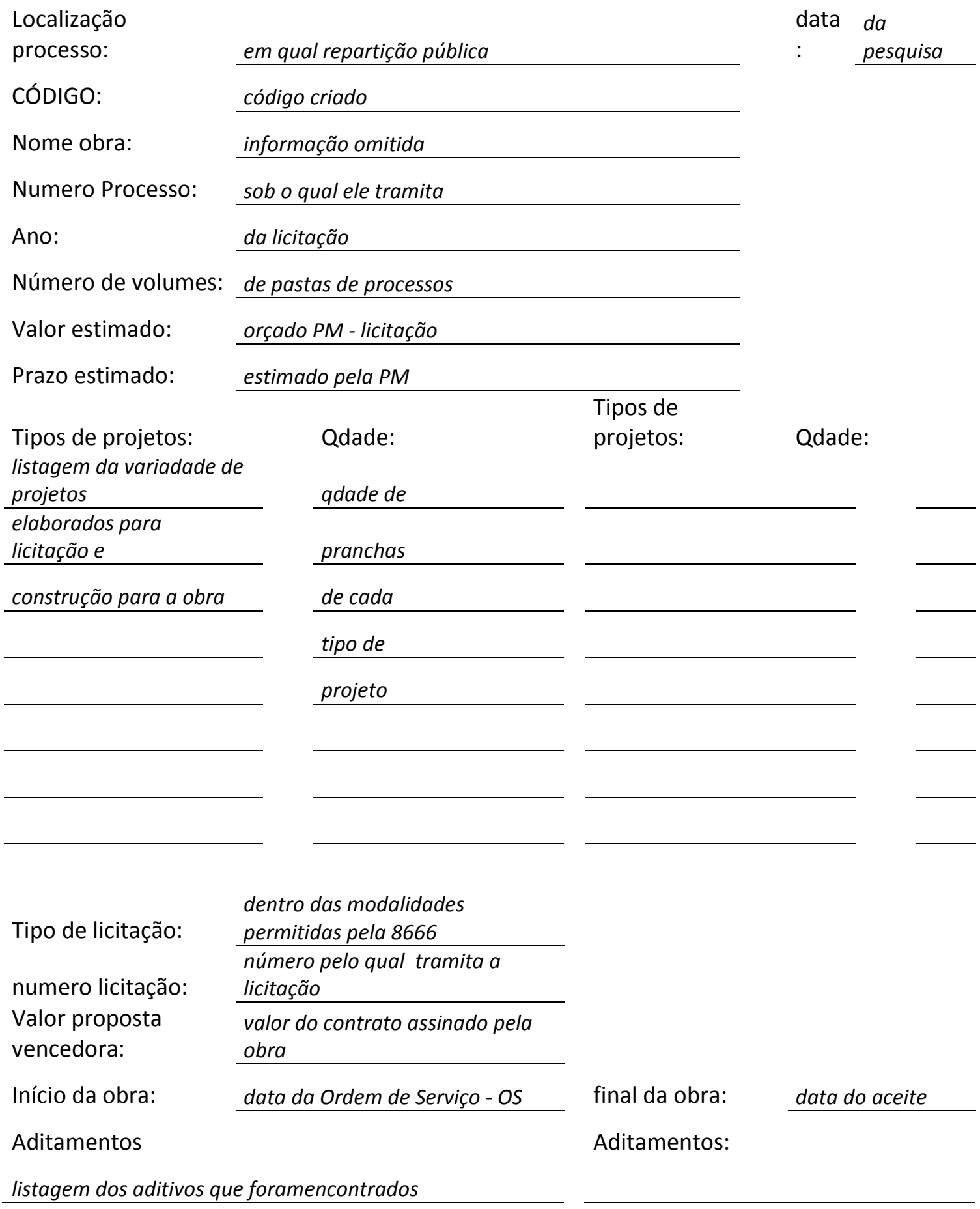


obs:

Anotações sobre processos jurídicos ou outra observação pertinente ao processo 


\section{ANEXO V}

Questionário respondido pelo engenheiro A da secretaria municipal.

Perguntas enviadas:

1. Qual a principal causa da grande quantidade de aditivos em obras da saúde e educação?

2. O que você acha que gera essa situação?

3. Você acha que esse problema pode ser resolvido? Se sim, você sugerem alguma solução?

4. Quais os procedimentos/ bases utilizadas para o desenvolvimento das planilhas orçamentárias?

5. Como é feita a contratação de projeto para essas obras?

6. Por que algumas licitações são abertas sem um projeto executivo completo?

Resposta recebida:

Qual a principal causa da grande quantidade de aditivos em obras da saúde e educação?

Os aditivos em obras de qualquer área, não se restringindo apenas à saúde e educação, ocorrem, principalmente, pelos seguintes motivos, inter-relacionados ou não:

- Ampliações ou reduções do objeto contratado que ocorrem pela oportunidade ou possibilidade do acréscimo de recursos financeiros ou pela necessidade de contingenciamento de recursos, situações comuns em órgãos públicos;

- Alterações no objeto contratado em função de alterações motivadas, por exemplo, por dinâmicas de demanda ou de utilização, que muitas vezes ocorrem 
devido a longos prazos decorridos entre a elaboração dos projetos e a execução das obras;

- Ampliações, reduções ou alterações do objeto por falhas no projeto básico;

- Alterações ou correções nas metodologias, especificações e quantificações do objeto contratado, por falhas no projeto básico.

Essas duas últimas situações acontecem pelo não atendimento da Lei 8.666 , Artigo 60, Item IX - Projeto Básico.

Na maior parte dos casos, utiliza-se, a título de Projeto Básico, estudos preliminares ou anteprojetos ou projetos legais. As especificações são genéricas e os quantitativos são apenas estimados (forma elegante de dizer "chutados").

Os órgãos públicos, na sua maioria, entendem, erroneamente, que levantamentos topográficos, sondagens, projetos estruturais e de instalações, entre outros, são elementos de projetos executivos.

$\mathrm{Na}$ verdade, o Projeto Executivo deve apresentar todos os detalhes construtivos de arquitetura e de instalações necessários à execução da obra, enquanto o Projeto Básico deve fornecer todas as informações necessárias e suficientes para atender os itens de a) a f) do Artigo 6으, Item IX - Projeto Básico da Lei 8.666, em vigor desde 21 de junho de 1993.

\section{O que vc acha que gera essa situação?}

A grande maioria dos municípios brasileiros não possui uma estrutura técnica multidisciplinar capaz de desenvolver projetos básicos nos termos da Lei 8666 ou Termos de Referência para a respectiva contratação.

Você acha que esse problema pode ser resolvido? Se sim, qual solução vc acha que seria possível? 
Tendo em vista a incapacidade financeira da maioria dos municípios brasileiros ( $80 \%$ dos municípios tem menos de 20 mil habitantes) em montar uma equipe técnica multidisciplinar para a elaboração de projetos básicos e licitações, a solução seria a criação de órgãos estaduais e/ou federais de apoio técnico para estas atividades.

Quais os procedimentos/bases utilizados para o desenvolvimento das planilhas orçamentarias?

As planilhas orçamentárias são compostas de especificações de serviços, respectivos quantitativos, custos e preços.

As especificações devem ser determinadas através dos memoriais descritivos do projeto básico.

As quantidades de cada serviço deverão ser calculadas a partir dos respectivos projetos.

E os custos devem ser obtidos, preferencialmente, na seguinte ordem: tabelas oficiais federais (p. ex. SINAPI e SICRO), estaduais (p. ex. DER, SABESP e FDE), tabelas municipais e cotações (mínimo de três por serviço).

Os preços resultam da aplicação do índice de BDI nos custos obtidos. Esse índice deve atender limites estabelecidos pelos órgãos de controle (TCU e TCE entre outros).

\section{Como é feita a contratação de projeto para essas obras?}

A contratação de um Projeto Básico deve ser feita a partir de um Termo de Referência elaborado por uma equipe técnica multidisciplinar do órgão público ou contratado com consultores especializados.

Por que algumas licitações são abertas sem um projeto executivo completo? 
As licitações de obras públicas devem ser montadas a partir de um Projeto Básico que atenda em sua totalidade o Artigo 60, Item IX da Lei 8.666 de 21/06/ 1993 (e não um Projeto Executivo, que detalha a execução da obra).

Essa exigência legal na maioria das vezes não é cumprida pelo fato de, principalmente as prefeituras, não terem um corpo técnico multidisciplinar para a elaboração de projetos ou dos respectivos termos de referência. 


\section{ANEXO VI}

Questionário respondido pelo engenheiro B da secretaria municipal.

Perguntas enviadas:

1. Qual a principal causa da grande quantidade de aditivos em obras da saúde e educação?

2. O que você acha que gera essa situação?

3. Você acha que esse problema pode ser resolvido? Se sim, você sugerem alguma solução?

4. Quais os procedimentos/ bases utilizadas para o desenvolvimento das planilhas orçamentárias?

5. Como é feita a contratação de projeto para essas obras?

6. Por que algumas licitações são abertas sem um projeto executivo completo?

Resposta recebida:

1 - As duas principais causas em obras da educação são: obras licitadas apenas com Projeto Básico e a baixa qualidade das empresas contratadas que não conseguem cumprir prazos. A bem da administração, para não perder o contrato e não interromper a obra por pelo menos dois (2) anos por conta de uma nova licitação, a administração optava por dar mais prazo para que a obra pudesse ser concluída. Outro problema comum advinha dos projetos fornecidos pelo FNDE, os quais necessitavam de ajustes e adequações às realidades locais, tanto realidades físicas quanto comportamental (usos diferenciados dos ambientes). Um fato que prejudica a execução é a elaboração dos projetos arquitetônico e complementares dentro do contrato de obra: as contratadas não elaboram os projetos e executam a obra sem aval da fiscalização e sem um projeto que especifique corretamente os serviços a executar. 
2 - Infelizmente, termos aditivos em contratos de obras são frequentes e praticamente uma regra. Primeiramente, é praticamente impossível que um projeto, mesmo um projeto executivo completo, não tenha algo a melhorar durante a execução que propicie um bem à administração, e em segundo lugar, para não trazer maiores prejuízos a administração, conforme comentei na resposta anterior, a administração decide por bem aceitar pedidos de prorrogação de prazo justificados.

3 - Uma boa parte do problema poderia ser resolvido com uma boa equipe técnica da administração (e bem gerenciada), quantidade de pessoal adequado para atender às demandas e infraestrutura de trabalho adequada a este corpo técnico para que:

a - A equipe tenha condição de fornecer, à equipe de licitação, em tempo hábil aos interesses públicos/políticos os critérios de seleção de propostas de projetos que seja a mais vantajosa à administração. Leia-se vantajosa como a melhor e não a de menor custo. Além disso, essa equipe deve ter condições de acompanhar e direcionar criteriosamente o desenvolvimento do projeto. Isso proporcionaria o recebimento de um projeto de alta qualidade reduzindo a possibilidade de aditivos para melhoria do objeto;

b - Uma vez licitado o projeto, a equipe tenha condição de fiscalizar detalhadamente cada etapa e que tenha em mãos ferramentas punitivas (multas e/ou suspensão contratual) àquelas empresas que não cumprem os prazos contratuais. A evolução da execução dos serviços devem seguir o cronograma físico-financeiro constante da proposta da contratada e, caso isso não seja cumprido, a contratada deve estar ciente que estará sujeita a multa caso não tenha uma justificativa plausível para o não cumprimento de sua própria proposta comercial vencedora do certame.

4 - As planilhas orçamentárias, junto com memoriais e desenhos, são produzidas por terceiros (contratação de projetos) e verificadas pela Divisão de Projetos. A verificação é dada com base nos preceitos de Orçamento de Obras para 
verificação dos serviços a executar e suas quantidades, seus preços devem ser aqueles publicados pelo CPOS, FDE, SINAPI, DER, TCPO ou outra fonte de preços públicos como por exemplo SIURB (cidade de São Paulo). Quando pequenos projetos são necessários, a SMOP produz a planilha conforme os preceitos de Orçamento de obras para especificação e quantificação dos serviços a executar e os preços utilizados, em sua maioria são da FDE e SINAPI.

5 - Para contratação de empresas para desenvolvimento de projetos, são levantados/cotados três propostas comerciais e contratado aquela propostas de menor valor para aqueles casos cujo preços de elaboração de projeto seja inferior a $\mathrm{R} \$$ $15.000,00$ (quinze mil reais). No caso de projetos cujo preço para seu desenvolvimento ultrapasse este valor, abre-se uma licitação.

6 - Algumas obras com baixa complexidade técnica de execução não exigem um alto nível de detalhamento, portanto, nestes casos específicos o Projeto Básico é suficiente para sua execução o que é permitido pela Lei 8666 a licitação de obras apenas com o Projeto Básico. Porém isso não pode ser regra, e sim exceção válida para casos específicos. 


\section{ANEXO VII}

Questionário respondido pelo engenheiro $\mathrm{C}$ da secretaria municipal.

Perguntas enviadas:

1. Qual a principal causa da grande quantidade de aditivos em obras da saúde e educação?

2. O que você acha que gera essa situação?

3. Você acha que esse problema pode ser resolvido? Se sim, você sugerem alguma solução?

4. Quais os procedimentos/ bases utilizadas para o desenvolvimento das planilhas orçamentárias?

5. Como é feita a contratação de projeto para essas obras?

6. Por que algumas licitações são abertas sem um projeto executivo completo?

Resposta recebida:

1. Muitas vezes as verbas para esses tipos de obras são provenientes de convênios firmados pela prefeitura com outros órgãos estaduais e federais, e quando é necessária a documentação técnica para efetivação dos mesmos, quase sempre próximo do vencimento, essa documentação é providenciada a toque de caixa em termos de projetos e orçamentos, não necessariamente nessa ordem.

2. Acho que a falta de integração por parte dos responsáveis no início dos pleitos das verbas e a falta de planejamento sobre que deva ser feito, sendo que a documentação técnica é relevada a planos posteriores.

3. Sim, uma solução seria um planejamento integrado das ações com projetos 
desenvolvidos até um nível executivo, ou a criação de um estoque aleatório de projetos.

4. As planilhas orçamentárias podem vir prontas onde é exigido que elas tem a base SINAPI, DER, PINI, FDE e etc. dependendo do tipo de serviço ou convênio, neste caso é feita a verificação e correção das planilhas recebidas. No caso de termos os projetos executivos sem as planilhas então é feito o levantamento dos serviços que serão necessários e ai as planilhas são elaboradas com as mesmas bases, ainda no caso de termos somente o projeto básico é feita uma estimativa dos serviços e posteriormente à contratação dos projetos executivos é feita uma correção das planilhas, normalmente gerando aditivos às mesmas.

5. Em função dos valores estabelecidos temos diversas modalidades de contratações

1-Contratação direta, até $\mathrm{R} \$ 15000,00$

2-Carta covite, até $\mathrm{R} \$ 150.000,00$

3-Tomada de preços, de $\mathrm{R} \$ 150.000,00$ a $\mathrm{R} \$ 1.500 .000,00$

4-Concorrência pública, acima de $\mathrm{R} \$ 1.500 .000,00$

NÃO TENHO CERTEZA - VALORES E MODALIDADES A CONFIRMAR

6. Porque a legislação permite e é uma forma, com certeza ineficaz, de agilizar a execução das obras. 


\section{ANEXO VIII}

Questionário respondido pelo engenheiro D da secretaria municipal.

Perguntas enviadas:

7. Qual a principal causa da grande quantidade de aditivos em obras da saúde e educação?

8. O que você acha que gera essa situação?

9. Você acha que esse problema pode ser resolvido? Se sim, você sugerem alguma solução?

10. Quais os procedimentos/ bases utilizadas para o desenvolvimento das planilhas orçamentárias?

11. Como é feita a contratação de projeto para essas obras?

12. Por que algumas licitações são abertas sem um projeto executivo completo?

Resposta recebida:

1 - A licitação é feita só com o projeto básico, ficando por conta da contratada a elaboração dos complementares de Estrutura, Instalações Elétricas e Hidráulicas, além da má qualidades de alguns dos projetos contratados.

2 - O problema acaba estourando na obra, inicialmente não tem como iniciar a obra sem os projetos de fundações, e depois vem os aditamentos de serviços inevitáveis.

3 - Sim, para resolver, ou minimizar o problema, todas as obras só deveriam ser licitadas com os projetos executivos executados e conferidos.

4 - Para a elaboração dos orçamentos, primeiramente é feito o estudo de todo o projeto executivo de arquitetura e os complementares se tiver. 
A partir do projeto é feito o levantamento das quantidades de serviços, (alvenaria, esquadrias, cobertura, etc.,), quando não tem os projetos complementares, é estimado com base na prática do orçamentista.

Depois é feito a composição dos preços unitários, (no caso das construtoras), ou no caso da prefeitura são utilizados os preços das tabelas oficiais do SINAPI, FDE, CPOS E DER, às vezes complementadas com os preços da Revista Construção - PINI e se o serviço não constar em nenhuma das tabelas acima, é feito a cotação dos materiais/serviços com 2 fornecedores e utilizado o preço médio.

Os quantitativos e os preços são inseridos na planilha orçamentária e acrescentado o BDI, Benefícios e Despesas Indiretas para se chegar ao preço final da obra.

5 - Normalmente é feita a cotação com 3 escritórios, quando é contratação direta. Para as obras maiores é feito a licitação por convite, tomada de preços, concorrência pública, etc.

6 - Muitas vezes na pressa de licitar para garantir verbas de convênios, ou nas obras corriqueiras e por determinação do planejamento, os projetos complementares são repassados para as contratadas, isso é permitido pela Lei 8666/93. 


\section{ANEXO IX}

Questionário respondido pelo engenheiro E da secretaria municipal.

Perguntas enviadas:

1. Qual a principal causa da grande quantidade de aditivos em obras da saúde e educação?

2. O que você acha que gera essa situação?

3. Você acha que esse problema pode ser resolvido? Se sim, você sugerem alguma solução?

4. Quais os procedimentos/ bases utilizadas para o desenvolvimento das planilhas orçamentárias?

5. Como é feita a contratação de projeto para essas obras?

6. Por que algumas licitações são abertas sem um projeto executivo completo?

Resposta recebida:

1. Os orçamentos são feitos com base nos projetos, mas ai sempre vinha a noticia de que tinhamos que abaixar o custo pq não tinha a verba suficiente. Então coisas essenciais acabavam sendo cortadas para diminuir o custo da obra.

2. Falta de planejamento. Para realizar uma obra, seria ideal que já tivessem a verba necessaria para todos os serviços, sem ter que cortar serviços necessários.

3. Sim. Tendo o orçamento completo, tentar conseguir a verba para o obra toda, sem ter que tirar serviços que podem fazer falta. 
4. Calcula-se as quantidades e os preços sao baseados na tabela sinapi, da caixa, ou cotaçoes de mercado.

5. É feita licitação ou contratação direta.

6. Por pressão, por terem pressa em licitar a obra. 